
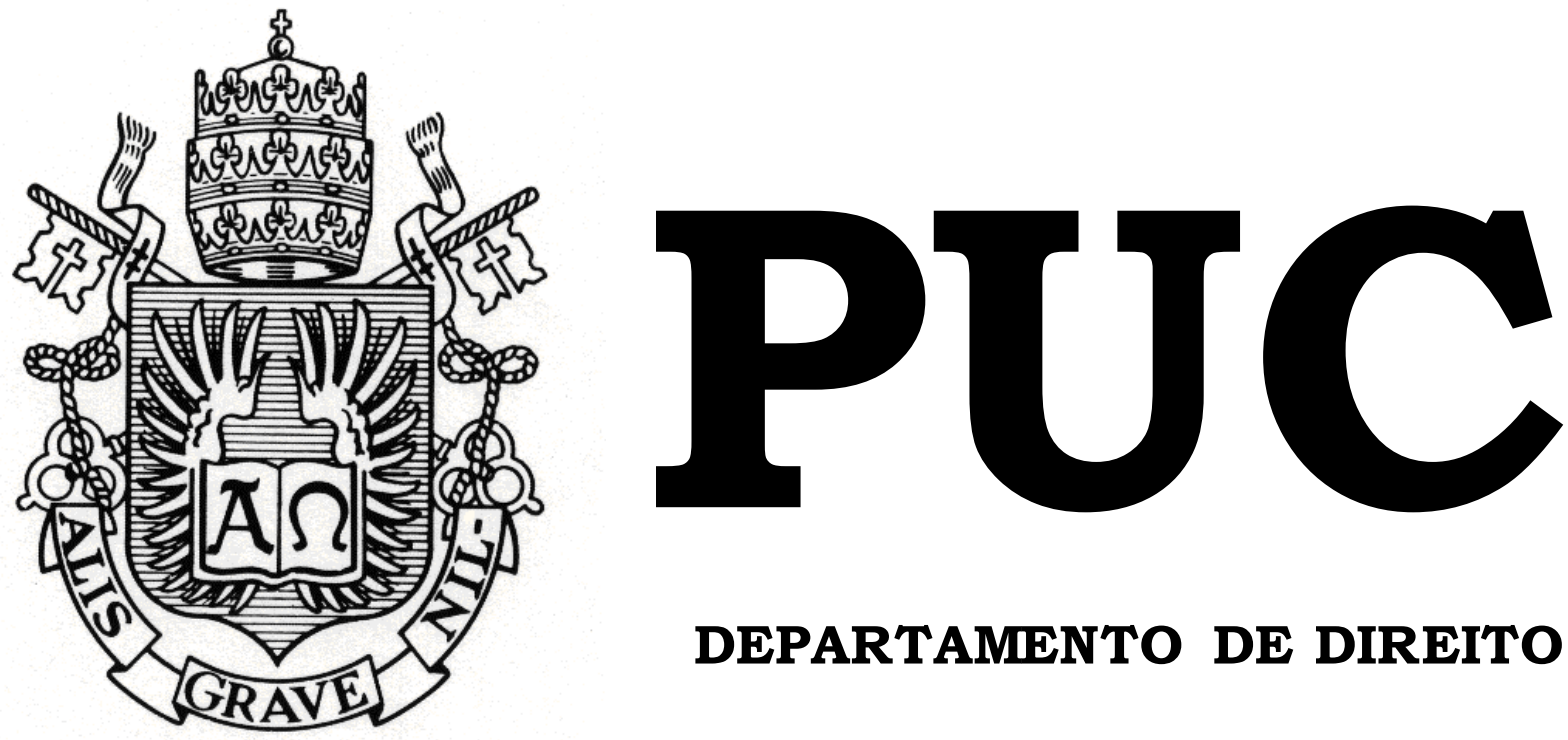

DEPARTAMENTO DE DIREITO

\title{
DEVERES E RESPONSABILIDADES DOS ADMINISTRADORES EM TRANSAÇÕES ENTRE PARTES RELACIONADAS
}

\author{
por \\ CAMILA COSTA REIS FAJARDO MARIOTTO \\ FERREIRA
}

ORIENTADORA: NORMA JONSSEN PARENTE

2018.1

PONTIFÍCIA UNIVERSIDADE CATÓLICA DO RIO DE JANEIRO RUA MARQUÊS DE SÃO VICENTE, 225 - CEP 22453-900 RIO DE JANEIRO - BRASIL 


\section{DEVERES E \\ RESPONSABILIDADES DOS \\ ADMINISTRADORES EM \\ TRANSAÇÕES ENTRE PARTES \\ RELACIONADAS}

por

Camila Costa Reis Fajardo Mariotto Ferreira

Monografia apresentada ao

Departamento de Direito da

Pontificia Universidade

Católica do Rio de Janeiro

(PUC-Rio) como requisito

parcial para a obtenção do título de Bacharel em Direito.

Orientadora: Norma Jonssen Parente 


\section{Agradecimentos}

Aos meus pais que me deram a vida e asas para voar por meus próprios caminhos. Muito obrigada por todo amor e força de sempre.

Ao meu irmão, por todo carinho e companheirismo diário, principalmente no último ano e nos momentos finais de conclusão do presente trabalho.

Aos meus avós, que mesmo partindo cedo, me deixaram grandes ensinamentos. Em especial à vó Clara, minha primeira professora, exemplo eterno de amor e carinho.

Às minhas amigas e amigos da faculdade. Em especial à Alice Catão, agradeço pela amizade, estudos, apoio e troca de conhecimentos diária. À Maria Isabel Tancredo, Johan Trindade, Rayan Kiffer, Júlia Rezende, Francisco Gradel e Joaquim Zanine, toda minha gratidão por serem minha família aqui no Rio.

À minha equipe do Levy \& Salomão por todos os ensinamentos e oportunidades de crescimento.

Aos professores e professoras que tanto me ensinaram ao longo de minha vida, em especial aos professores de Direito Empresarial da PUC que com suas lições, despertaram em mim o interesse acadêmico pela matéria, que tanto me auxilia, ainda que indiretamente, em minha vida profissional.

À minha orientadora, Professora Norma Parente, por aceitar me orientar e apontar a importância de estudo do tema. Muito obrigada pelas aulas, material, e conversas que foram valiosas para a conclusão desse estudo. 


\section{Resumo}

O presente trabalho tem por objetivo analisar o tratamento dado aos deveres e responsabilidades dos administradores em transações entre partes relacionadas. Inicialmente, apresenta o que são transações entre partes relacionadas e considerações sobre o tema. Após, enuncia os deveres e responsabilidades dos administradores ao se depararem com esse tipo de transação. Ao final, apresenta os parâmetros utilizados para analisar a conduta dos administradores.

\section{Palavras-chave}

Business Judgment Rule; Comissão de Valores Mobiliários; Conflito de Interesses; Delaware; Dever de Diligência; Dever de Informar; Dever de Lealdade; Direito Societário; Fairness Test; Mercado de Capitais; Monografia; Transações Entre Partes Relacionadas; União Europeia; Pontifícia Universidade Católica do Rio de Janeiro. 


\section{Sumário}

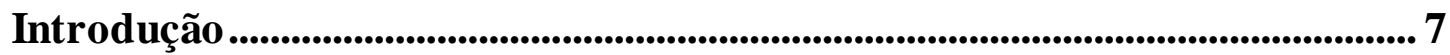

Capítulo 1 - Transações entre partes relacionadas ..................................................9

Capítulo 2 - A natureza do vínculo do administrador com a companhia .12

Capítulo 3 - Deveres e responsabilidades dos administradores....................... 16

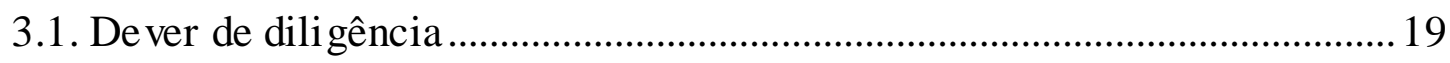

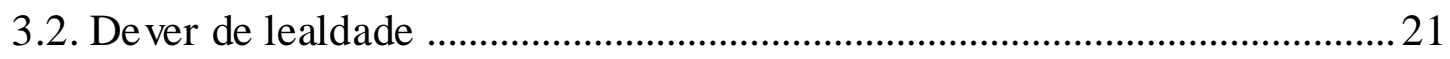

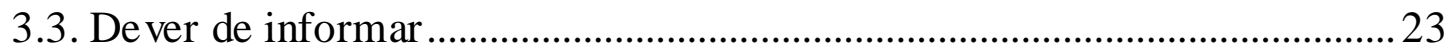

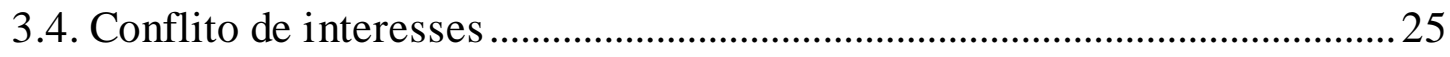

3.5. Deveres dos administradores decorrentes de soft laws ...................................32

3.5.1. Comissão de Valores Mobiliários (CVM) ………………………………....... 34

A) Instruções e Deliberações da CVM ..................................................................... 34

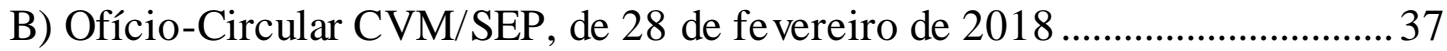

C) Parecer de orientação $\mathrm{CVM} \mathrm{n}^{\circ} 35$, de $1^{\circ}$ de setembro de 2008 ........................38

3.5.2. Instituto Brasileiro de Governanç a Corporativa (IBGC) ............................ 41

3.5.3. Associação Brasileira das Companhi as Abertas (ABRASCA) ................ 42

Capítul o 4 - A regulamentação de Transações entre partes relacionadas em outras jurisdições ...................................................................................................................4 46

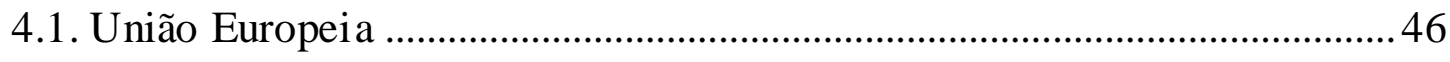

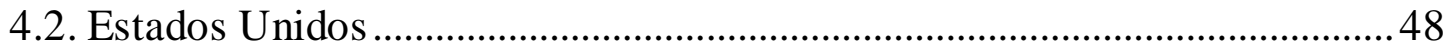

4.2.1. Statement of Finacial Accounting Standards............................................4 48

4.2.2. General Corporation Law (Delaware) ..................................................... 49

Capítulo 5 - A Responsabilidade do Administrador em Transações entre Partes Relacionadas ..........................................................................................................50 
5.1 Parâmetros para verificação da conduta do administrador ..........................52

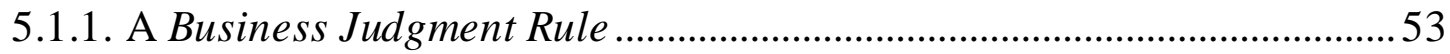

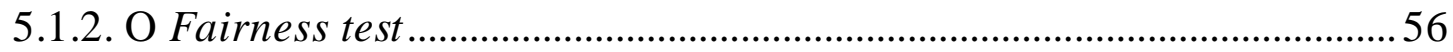

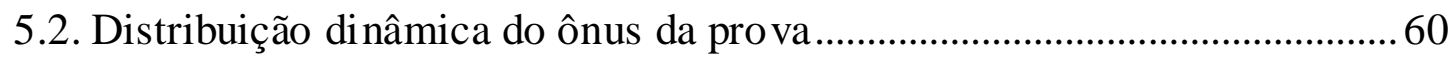

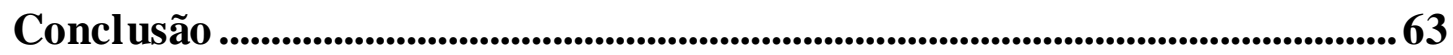

Referências Bibliográficas .........................................................................................65 


\section{Lista de Abreviações}

ABRASCA - Associação Brasileira das Companhias Abertas

Art. - artigo

CVM - Comissão de Valores Mobiliários

FASB - Financial Accounting Standards Board

IBGC - Instituto Brasileiro de Governança Corporativa

P. - página

PAS - Processo Administrativo Sancionador

TRPs - Transações entre Partes Relacionadas

TPRs - Transações entre Partes Relacionadas 


\section{Introdução}

Transações entre partes relacionadas podem ser conceituadas como operações em que as partes possuem algum vínculo que possa influenciar no desfecho do negócio. Um dos grandes dilemas sobre a abordagem do tema decorre de duas possíveis perspectivas de análise deste que pode ser visto como (i) prática de favorecimento do acionista controlador ou do administrador; ou (ii) ferramenta eficiente de organização empresarial. Analisada por ambas as perspectivas, tais operações despertam preocupação em juristas e agentes econômicos, principalmente, pelo seu potencial conflito de interesses.

Dada sua relevância para o mercado, analisadas sob o aspecto econômico, as transações entre partes relacionadas não devem ser proibidas. Porém, sob o enfoque jurídico é preciso ter um olhar mais crítico sobre o tema e estabelecer padrões de conduta para que interesses particulares não prevaleçam sobre o interesse social das companhias e o sistema acionário não seja comprometido com o uso indevido desse tipo de transações. ${ }^{1}$

Partindo dessa ideia de que transações entre partes relacionadas merecem um estudo particular, o presente trabalho tem o objetivo de analisar a regulação da matéria e os limites de atuação do administrador para que não haja conflito de interesses, tampouco prejuízo aos acionistas ou à companhia.

O primeiro capítulo apresentará o que são transações entre partes relacionadas. O segundo discorrerá sobre a natureza do vínculo entre o administrador e a companhia. O terceiro apresentará os principais deveres dos administradores de sociedades anônimas que decorrem da lei e de soft laws, sem deixar de mencionar padrões de conduta ou standards, já consolidados pela doutrina e pela jurisprudência² .

\footnotetext{
${ }^{1}$ CAMARGO, João Laudo de; BASTOS FILHO, Cláudio Luiz de Miranda. Transações entre partes relacionadas. In CASTRO, Leonardo Freitas de Moraes e (Org.). Mercado Financeiro \& de Capitais: Regulação e Tributação - São Paulo: Quartier Latin, 2015, p. 248.

${ }^{2}$ Diante da impossibilidade de prever, exaustivamente, todos os deveres dos administradores, a lei acaba por adotar conceitos indeterminados e abstratos, que apenas se concretizam na análise de cada caso.
} 
No quarto capítulo será apresentada a regulamentação de transações entre partes relacionadas em outras jurisdições e no quinto, a responsabilidade do administrador será analisada com a exposição de dois parâmetros para verificação de sua conduta. As premissas clássicas que compõe o business judgement rule e estabelecem como o administrador deve agir serão mais uma vez exploradas. Ademais será introduzido um estudo da aplicação do instituto do Fairness Test pela jurisprudência de Delaware na análise da conduta dos administradores ao se depararem com transações entre partes relacionadas.

Por fim, será apresentada a teoria da distribuição dinâmica do ônus da prova, introduzida ao ordenamento jurídico brasileiro com a Lei n. 13.105 de 2015 e analisada a possibilidade de inverter o ônus probatório, apontando um possível caminho para verificação da responsabilidade do administrador em transações entre partes relacionadas. 


\title{
Capítulo 1 - Transações entre partes relacionadas
}

\author{
Transações entre partes relacionadas ${ }^{3}$ são um fenômeno comum no \\ âmbito corporativo. Exatamente por isso, muitas jurisdições estabelecem \\ normas ou até mesmo deveres de conduta específicos para esse tipo de transação \\ buscando evitar abusos de poder ou decisões que não sejam no interesse da \\ companhia.
}

Em síntese, transações entre - ou com partes relacionadas - podem ser conceituadas como operações

Realizadas pela sociedade empresária com determinadas pessoas, cujas posições, direta ou indiretamente, as colocam em situações nas quais as deliberações dos competentes órgãos sociais possam vir a ser indevidamente por elas influenciadas, com o risco de que tais deliberações não sejam tomadas em bases adequadas, comprometendo o interesse social. ${ }^{4}$

Devido seu potencial conflito de interesses essas transações merecem ter uma regulamentação específica, que assegure um alto grau de transparência e consequente monitoramento de eventual desalinhamento com o interesse social. 56

\footnotetext{
3 “(...) a term of art that usually comprises conterparties who, thanks to their influence over corporate decision makers, may secure better terms of themselves than they would get following arm's-length bargaining." Tradução livre: (...) um termo que geralmente compreende partes que, graças à sua influência sobre os tomadores de decisões corporativas, podem obter melhores termos para si mesmos do que obteriam em negociações em condições de mercado." Luca Enriques, Related Party Transactions, Oxford Handbook of Corporate Law and Governance, Oxford, Oxford Handbooks Online, 2015, p. 1

${ }^{4}$ CAMARGO, João Laudo de; BASTOS FILHO, Cláudio Luiz de Miranda. Transações entre partes relacionadas. In CASTRO, Leonardo Freitas de Moraes e (Org.). Op. cit., p. 252.

${ }^{5}$ Ibid., p. 251.

${ }^{6}$ Nas palavras de João Laudo de Camargo e Cláudio Luiz de Miranda Bastos Filho: "As transações entre partes relacionadas se enquadram como espécie do gênero "conflito de interesses", sendo importante estabelecer um eficiente e pontual regramento do tema, permitindo o pertinente monitoramento do conteúdo dessas operações e dos seus processos de negociação e de decisão. Dessa forma, não é suficiente o simples atendimento ao padrão de conduta legal - "cuidado e diligência que todo homem ativo e probo costuma empregar na administração dos seus próprios negócios": exigem-se dos administradores uma prudência e atenção ainda maiores quando da negociação de TPRs ". Ibid., p. 251.
} 
Conforme será abordado mais a frente, a identificação de transações entre partes relacionadas é importante, uma vez que tais operações devem receber tratamento diferenciado no que tange ao padrão de conduta do administrador. Isso porque:

Em transações entre partes independentes, presume-se a independência negocial do administrador, a sua boa-fé. Por outro lado, é característico das transações com partes relacionadas -TRPs a "ausência dessa independência negocial, quando, muitas vezes, uma das partes é capaz de influenciar na vontade da outra". ${ }^{7}$

Para entender a disciplina da matéria, importante definir os elementos determinantes em uma operação para que seja conceituada como entre partes relacionadas. Nesse ponto, se destaca que sua caracterização pode ser formal ou informal, via vínculos contratuais, de fato, societários, familiares, entre outros.

Dentre os principais exemplos de transações entre partes relacionadas, estão aquelas que se dão entre sociedades controladoras, controladas ou sob controle comum ou aquelas que se dão entre a sociedade e seus respectivos sócios, administradores ou parentes. Alguns exemplos mais concretos são os de transações em que administradores ou controladores celebram negócios com a própria companhia, também conhecido como self-dealing, ou participam da tomada de decisão sobre a atribuição de remuneração dos administradores.

O presente estudo tem como escopo a análise de como deve atuar o administrador ao se deparar com transações entre partes relacionadas. Tal opção se deu a partir da percepção de que na maioria das vezes a análise do tema é voltada para atuação de acionistas em transações entre partes relacionadas.

Sem deixar de considerar que (i) muitas vezes o administrador acaba por ser uma extensão da vontade dos acionistas ${ }^{8}$ - principalmente no Brasil, onde

\footnotetext{
7 PARENTE, Norma Jonssen; coordenação Modesto Carvalhosa. Mercado de Capitais. (Coleção Tratado de Direito Empresarial. v. 6). São Paulo: Editora Revista dos Tribunais, 2016, p. 545.
} 
não se verifica uma grande dispersão acionária -, bem como que (ii) o tratamento que as entidades auto reguladoras dão às transações entre partes relacionadas é muito semelhante, sendo a parte relacionada administrador ou acionista, se verifica atualmente, um esforço regulatório para transferir poderes dos acionistas aos órgãos de administração da companhia, mitigando assim as possibilidades de abuso de poder dos administradores e dos controladores. Nesse contexto, se mostra importante o estudo dos deveres dos administradores ${ }^{9}$ em transações entre partes relacionadas.

\footnotetext{
9 "De fato, a atividade do administrador da sociedade anônima, notadamente sob a ótica de seus deveres e responsabilidades, é o ponto que tem merecido maior atenção dos legisladores e estudiosos, muito embora - e talvez- por is so mes mo - não se tenha gas to muitos artigos de lei para dis por sobre o as sunto. A razão para essa atenção decorre de ser este aspecto um dos mais importantes no que toca ao funcionamento da sociedade anônima - ao lado do reconhecimento da figura do acionista controlador, tema que também recebeu o tratamento adequado e pioneiro da LSA - e representa o centro de gravidade da relação interna da companhia”. SAMPAIO CAMPOS, Luiz Antonio de. Deveres $e$ Responsabilidades. In LAMY FILHO, Alfredo; PEDREIRA, José Luiz Bulhões (Org.). Direito das Companhias. Rio de Janeiro: Forense, 2017. p. 790.
} 


\section{Capítulo 2 - A natureza do vínculo do administrador com a companhia}

Antes de dar início à análise dos deveres dos administradores em Transações entre Partes Relacionadas, cumpre apresentar brevemente as discussões referentes à natureza do vínculo dos administradores com a companhia, ainda que tal discussão já tenha sido superada por grande parte da doutrina ao adotar a teoria organicista.

Nas palavras de Marcelo Adamek:

A definição da natureza jurídica pela qual os administradores se vinculam à sociedade que administram é questão das mais delicadas e controvertidas. Para além da confusão incorrida por muitos estudiosos (que não se aperceberam das diferenças entre a natureza da administração como elemento integrante da pessoa jurídica e a relação entre a pessoa jurídica e os membros do órgão de administração), existem múltiplas teorias que se propõe a deitar luz sobre esse tema. ${ }^{10}$

Sem a pretensão de esgotar a matéria, o estudo da natureza de tal vínculo, normalmente, se divide em três linhas teóricas: contratualistas, unilateralistas e dualistas.

Em síntese, as teorias contratualistas partem da ideia de que o vínculo jurídico entre a administração e a companhia seria contratual. Já as unilateralistas, verificam nesse vínculo atos jurídicos unilaterais contrapostos. ${ }^{11}$ Por fim, as teorias dualistas defendem a existência de duas relações jurídicas, distintas e com objetos próprios.

\footnotetext{
10 ADAMEK, Marcelo Vieira Von. Responsabilidade Civil dos Administradores de S/A (e as ações correlatas) - São Paulo: Saraiva, 2009, p. 39.

${ }^{11}$ Marcelo Adamek ensina que tais atos unilaterais contrapostos seriam de um lado, ato unilateral da sociedade de nomeação de adminis trador, originário da as sembleia ou outro órgão competente e de outro lado seria a aceitação por parte do administrador. Nesse sentido, "aceitação e nomeação permaneceriam como atos unilaterais, distintos e autônomos". (Ibid., p. 40.)
} 
Nos países de common law destacam-se também as teorias da agency e do trust.

A teoria da agency, foi definida por Jensen e Meckling em 1976 como um contrato em que uma ou mais pessoas contrata o agente para realizar algum serviço ou trabalho em seu favor. Esse contrato envolve a delegação de autoridade para o agente tomar a melhor decisão em troca de uma remuneração. ${ }^{1213}$

No mesmo sentido, a teoria do Trust, de grande importância no direito anglo saxão, tem como característica fundamental a divisão entre patrimônio e propriedade. Tal característica possibilita que o administrador do patrimônio, no caso do presente estudo, o administrador da companhia, seja pessoa diversa do titular da propriedade.

Segundo Adamek, o entendimento majoritário nessa intrincada matéria, é de que a relação entre o administrador e a companhia seria um contrato de

12 "There are three components of this definition given by Jensen and Meckling (1976). First is the existence of a contract between a principal and an agent. The second is a performance of a service. The third is delegation of decision-making authority. According to Berreca and Gupta (1999, p.184) the objective of agency theory is to design a contract that minimises the cost of service performed by the agent to the principal. The agent needs to work for the principal under certain const raints. The first constraint is known as the participation constraint when the agent needs to agree to work for the principal. The second is the incentive constraint when the agent needs to work hard for the principal despite disutility of the work for the agent. The principal bears the risk of his/her delegation to the agent and carry the cost and benefit of the delegation." Tradução livre: Existem três componentes desta definição dada por Jensen e Meckling (1976). O primeiro é a existência de um contrato entre um principal e um agente. O segundo é um desempenho de um serviço. O terceiro é a delegação de autoridade decisória. Segundo Berreca e Gupta (1999, p.184), o objetivo da teoria da agência é projetar um contrato que minimize o custo do serviço realizado pelo agente para o principal. $\mathrm{O}$ agente precisa trabalhar para o principal sob certas restrições. A primeira restrição é que o agente precis a concordar em trabalhar para o principal. A segunda é a restrição de incentivo quando o agente precisa trabalhar duro para o principal, apesar da desutilidade do trabalho para o agente. O principal assume o risco do que delega ao agente e arca com os custos e benefícios da delegação. (Bhati, S. S. (2015). Relation between trust theory and agency theory. In S. Natarajan, M. Ganesh. Babu, B. Nagarjuna \& R. Rajkumar (Eds.), Commerce and Management - A Modern Perspective (p. 57-65). India: Archers and Elevators Publishing House.)

13 “Os agentes, ao atuarem como órgãos sociais, devem ter o interesse coletivo dos sócios como exclusivo vetor de suas condutas, em obediência ao dever fiduciário que possuem para com a entidade da qual participam. O agente é a pessoa que toma decisões e as executa, desincumbindo-se do "poderdever" inerente ao seu cargo em prol do interesse do principal (da sociedade e dos s eus acionistas), devendo, para tanto, relegar a segundo plano, ou mes mo afastar, seus próprios interes ses ou aqueles das pes soas a ele vinculadas com laços, cuja natureza pos sa comprometer a sua independência. CAMARGO, João Laudo de; BASTOS FILHO, Cláudio Luiz de Miranda. Op. cit., p. 249. 
administração sui generis ${ }^{14}$. Tal contrato pode ser qualificado como bilateral e tem como objeto uma obrigação de meio.

Por outro lado, Francesco Galgano entende ser inadequado definir o contrato de administração como um contrato sui generis, porque concebe os poderes dos administradores como derivados, que tem como fonte o contrato de administração entre a companhia e os administradores, quando na verdade são poderes originários, ou seja, poderes que os administradores, na sua condição de órgãos necessários para a execução do contrato de sociedade recebem diretamente desse contrato. ${ }^{15}$

Nesse sentido, conclui que:

A nomeação dos administradores, seguida pela aceitação por parte dos mesmos, não é um ato de atribuição de poderes; é, mais simplesmente, o ato que designa as pessoas escolhidas para o órgão ao qual, por lei é atribuído o dever de executar o contrato; e as pessoas, uma vez escolhidas, exercerão os poderes e cumprirão as correlativas obrigações inerentes à função que é própria do órgão. ${ }^{16}$

Não obstante as teorias apresentadas, o moderno direito societário já consolidou a teoria organicista para explicar a natureza do vínculo entre administradores e sociedade. ${ }^{17}$

Com base na teoria organicista foi desenvolvida a ideia de que os administradores como órgão da sociedade, presentam a própria sociedade e não atuam em nome dela.

\footnotetext{
${ }^{14}$ ADAMEK, Marcelo Vieira Von. Op. cit., p. 48.

15 De acordo com ADAMEK, Marcelo Vieira Von. Op.cit., p. 51, apud GALGANO, Francesco Galgano, Derecho comercial, cit., v. 2, n. 10.13, p. 375; La società per azioni, cit., n. 3, p. 272; e Il nuovo diritto societário, cit., n. 3, p. 253. Com igual registro: Massimo Franzoni, La responsabilità civili degli amministratori di società di capitali. In: Trattato di diritto commerciale e di diritto pubblico dell'economia - diretto de Francesco Galgano, Padova: CEDAM, 1994, v. 19: La responsabilità degli amministratori e dei sindaci, n. 2, p. 9-10.

${ }^{16}$ De acordo com ADAMEK, Marcelo Vieira Von. Op.cit., p. 51 apud FRANCESCO Galgano, Op. cit, p. 254/255.

${ }^{17}$ EIZIRIK, Nelson; GAAL, Ariádna B.; PARENTE, Flávia; HENRIQUES, Marcus de Freitas, Mercado de Capitais - regime jurídico. 3.ed. revis ta e ampliada. - Rio de Janeiro: Renovar, 2011, p. 420.
} 
Além disso, uma vez que a Lei de Sociedades Anônimas enuncia direitos e deveres dos administradores, a discussão da natureza da responsabilidade do administrador perde grande importância. É o que entende Sampaio Campos:

(...) como a LSA não faz referência a mandato, mas em vez disso, prevê deveres e responsabilidades específicas, deixa de ter relevância qualquer discussão tanto no que diz respeito à adoção da figura do mandatário, que a lei, de fato, não perfilhou, quanto no que se refere à natureza dessa responsabilidade. Discussões ocorreram no passado, mas já estavam mais do que consolidadas quando da elaboração do anteprojeto, que abraçou a solução que entendeu pertinente. ${ }^{18}$

Por fim, importante ressaltar, que ainda que os poderes e atribuições dos administradores estejam definidos pela própria lei ${ }^{19}$, a companhia pode e deve respeitar à normas editadas por órgãos de auto regulação, bem com editar suas próprias normas internas. No caso de transação entre partes relacionadas, como se verá mais a frente, a implementação de políticas internas para tratar do tema é extremamente recomendável.

${ }^{18}$ SAMPAIO CAMPOS, Luiz Antonio de. Op. cit., p. 800.

19 "O certo é que o poder de gestão social sujeita os administradores a um conjunto de normas cogentes, objetivando delinear um padrão de conduta exigido pela própria condição de gestores do patrimônio alheio e estabelecer, a priori, as consequências de eventual violação culposa ou dolosa das obrigações previstas no estatuto". CUNHA, Rodrigo Ferraz Pimenta da, Estrutura de Interesses nas Sociedades Anônimas - Hierarquia e Conflitos - São Paulo: Quartier Latin, 2007 apud TEIXEIRA, Guerreiro. Das sociedades anônimas no direito brasileiro, p. 741. 


\section{Capítulo 3 - Deveres e responsabilidades dos administradores}

Os deveres dos administradores têm como fundamento não apenas a lei, mas também os estatutos e as deliberações sociais. Alguns estudiosos ${ }^{20}$, em razão da confiança que as partes depositam aos administradores, também dão tratamento fiduciário a esses deveres, exigindo-lhes que sua atuação seja pautada pela boa-fé e diligência.

Considerando a cisão entre propriedade e gestão na administração de sociedades anônimas, a imposição de tais deveres, assim como de padrões de conduta aos administradores, se mostra ferramenta essencial para mitigar os riscos de tomadas de decisões que não sejam no interesse da companhia. Com efeito, tais deveres acabam por servir como controle a priori das condutas dos administradores.

Ressalta-se desde logo, que os padrões de conduta dos administradores são uma espécie de cláusula geral. Isso porque, como mencionado anteriormente, ante a dificuldade de prever exaustivamente todos os deveres dos administradores, o legislador adota na Lei de Sociedades Anônimas conceitos indeterminados e abstratos, melhor dizendo standards, para que sua conduta seja analisada de acordo com as

\footnotetext{
${ }^{20}$ Dentre eles destacam-se, PARENTE, Norma Jonssen; coordenação CARVALHOSA, Modesto, Op. cit., p. 491 e SALOMÃO FILHO, Calixto, O novo direito societário, $3^{\mathrm{a}}$ edição, revista e ampliada. São Paulo, 2002, p. 69.
} 
especificidades de cada caso concreto. ${ }^{2122}$

Não obstante os padrões de conduta dos administradores tenham tal nível de abstração, o legislador brasileiro foi detalhista ao enunciar um elenco de deveres e responsabilidades entre os arts. 153 e 158 da Lei de Sociedades Anônimas, que funcionam como uma espécie de matriz para os demais deveres essenciais para os administradores participantes do mercado de capitais. ${ }^{23}$

É o que nos ensina Nelson Eizirik, Ariádna B.Gaal, Flávia Parente, Marcus de Freitas Henriques; e Marcelo Adamek, respectivamente:

O legislador brasileiro adotou um critério misto: se por um lado, descreve os deveres e as obrigações impostas aos administradores de maneira "minuciosa, até pedagógica", como esclarece a Exposição de Motivos da Lei Societária, por outro, utiliza standards ou referências genéricas e abstratas para esclarecer alguns deveres. ${ }^{24}$

O legislador pátrio, palmilhando a mesma rota trilhada pelas mais modernas leis societárias, em vez de procurar inutilmente restringir a atuação e o poder decisório dos administradores, por meio de preceitos rígidos e específicos para cada um dos múltiplos acontecimentos da vida negocial - no que certamente teria fracassado e contribuído para gerar maiores ineficiências por meio de um sistema inflexível - , corretamente optou, de um lado, por preservar a liberdade de atuação dos administradores, conferindo-lhes atribuições e poderes privativos e (consequentemente) indelegáveis (LSA, arts. 138, § $1^{\circ}$, 139 e 144), e, de outro lado, resolveu pautar o comportamento dos administradores por padrões de conduta gerais e abstratos, verdadeiras cláusulas gerais a serem contrastadas com sua

21 SAMPAIO CAMPOS, Luiz Antonio de. Op. cit. p. 790. Destaca que os standards conferem ao interprete e ao aplicador da lei certa liberdade ou largueza de interpretações. Nesse sentido, defende a importância de que essa liberdade "deve ser usada de forma inteligente e cuidadosa, a manter o sistema íntegro, para não desencorajar e afastar pessoas honestas e competentes dos cargos de adminis tradores, e também de modo a não criar um sistema que as entorpeça a ação com uma burocracia prejudicial à vida da companhia, afastando-as do risco inerente ao negócio".

22 Nesse sentido são as palavras dos ilustres doutrinadores Nelson Eizirik, Ariádna B. Gaal, Flávia Parente e Marcus de Freitas Henriques: “(...) embora consignados expressamente na Lei, tais deveres representam padrões de conduta ou standards a serem observados. Isto é, não são formulados em caráter absoluto, nem possuemum conteúdo fixo, dependendo das particularidades de cada caso concreto. Vale dizer, os standards expressam condutas sociais médias, de caráter enunciativo, que funcionam como diretivas genéricas e servem como medida ou elemento de comparação para o juízo de casos concretos. Daí, comportarem tais standards forte carga de subjetivismo, implicando um certo juízo de valor sobre a conduta". EIZIRIK, Nels on; GAAL, Ariádna B.; PARENTE, Flávia; HENRIQUES, Marcus de Freitas, Op. cit., p. 424.

${ }^{23}$ PARENTE, Norma Jonssen; coordenação CARVALHOSA, Modesto, Op. cit., p. 493.

${ }^{24}$ EIZIRIK, Nelson; GAAL, Ariádna B.; PARENTE, Flávia; HENRIQUES, Marcus de Freitas, Op. cit, p. 423. 
atuação específica em casa caso concreto (LSA, art. 153 a 157) ${ }^{25}$, em clara aproximação à técnica legislativa da common law. ${ }^{26} 27$

Os principais deveres dos administradores enunciados pela Lei de Sociedades Anônimas, em sua seção VI, do capítulo 3, são: (i) o dever de diligência (art. 153); (ii) o dever de lealdade (art. 155); (iii) o dever de informar (art. 157); e (iv) os deveres decorrentes do conflito de interesses (art. 156). ${ }^{28}$ Além de tais deveres explícitos, também existem deveres específicos enunciados ao longo da lei, bem como deveres implícitos 29

O presente capítulo, apesar de reconhecer a importância dos diversos deveres dos administradores se ocupará por analisar de forma mais detida os deveres de diligência, lealdade, de informar e os deveres decorrentes de conflito de interesses do administrador. Isso porque, são os mais relevantes para a análise de transações entre partes relacionadas.

Antes de iniciar a descrição dos padrões supramencionados, importante mencionar ainda, que a Lei de Sociedades Anônimas adota um sistema de deveres e responsabilidades dos administradores no geral, sem distinção de tratamento entre diretores e membros do Conselho de Administração. Exatamente por isso, ao aplicar a lei é preciso analisar as especificidades de cada órgão. ${ }^{30}$

\footnotetext{
25 Wilson de Souza Campos Batalha entende serem "parâmetros ou standards jurídicos, que indicam diretrizes genéricas a serem apreciadas pelo prudente critério do julgador" (Comentários à Lei das Sociedades Anônimas, Rio de Janeiro: Forense, 1977, v. 2, p. 697). A rigor, o sistema normativo da lei acionária compreende normas dotadas de conceitos jurídicos indeterminados e cláusulas -gerais, umas e outras típicas de um sistema normativo móvel e aberto: são enunciações abstratas feitas pela lei, a exigir valoração para que o aplicador possa preencher o seu conteúdo; nas primeiras, preenchido o conteúdo, a consequência é dada pela lei e, nas segundas a solução é elaborada em concreto. (ADAMEK, Marcelo Vieira Von, Op. cit., p. 113).

${ }^{26}$ NETO, Eduardo Salomão, O “trust”' e o direito brasileiro, n. 5.1.3, São Paulo: LTr, 1996, p. 114/115.

27 Adamek, Marcelo Vieira Von. Op. cit., p. 113.

28 Sobre a divisão dos deveres dos administradores adotada acima, importante destacar que os doutrinadores estabelecem múltiplas divisões sobre o tema. Inobstante as diversas class ificações adotadas para melhor analisar a matéria, é possívelverificar um entendimento dominante no sentido de que os principais deveres dos administradores são os deveres de diligência e lealdade.

${ }^{29}$ ADAMEK, Marcelo Vieira Von. Op. cit., p. 120.

${ }^{30}$ SAMPAIO CAMPOS, Luiz Antonio de. Op. cit., p. 797.
} 


\subsection{Dever de diligência}

$\mathrm{O}$ art. 153 da Lei de Sociedades Anônimas ${ }^{31}$, enuncia os deveres de cuidado e de diligência (duty of care) do administrador da companhia no exercício de suas funções, por meio de um conceito aberto, cabendo à doutrina e a jurisprudência desenvolver seus principais aspectos.

O dever de diligência pode ser considerado o dever de maior abrangência imposto aos administradores pela Lei de Sociedades Anônimas. Isso porque, a maior parte dos padrões de conduta decorrem desse dever.

A lei brasileira adota o critério do homem ativo e probo, que não parece ser a melhor opção para analisar o dever de diligência de um administrador de uma companhia. ${ }^{32}$ Isso porque, se espera que o administrador assuma riscos para obter mais lucro e os atributos de um homem ativo e probo não asseguram esse desempenho esperado de um administrador.

Apesar da Lei de Sociedades Anônimas manter o critério de diligência enunciado no Decreto-Lei $\mathrm{n}^{\circ} 2.627$, de 26 de setembro de 1940, em tempos modernos, o padrão de conduta do administrador deve se aproximar ao comportamento do businessman do direito anglo-saxão, e não do pater familie.

A propósito, o diretor relator Henrique Balduino Machado Moreira, em sessão de julgamento do PAS CVM RJ2013/9266, em março de 2018, ao analisar o dever de diligência adotou o critério do businessman:

No caso concreto, ao avaliar a decisão do acusado de ter-se mantido inerte diante da operação, vê-se que dele esperava-se mais. Esperava-se, de um homem de negócios, uma conduta mais atenta e diligente, que deveria, no mínimo, ter-se insurgido

\footnotetext{
${ }^{31}$ Art. 153. O administrador da companhia deve empregar, no exercício de suas funções, o cuidado e diligência que todo homem ativo e probo costuma empregar na administração dos seus próprios negócios.

32 Marcelo Adamek consigna que o standard adotado pela lei brasileira para caracterizar o dever de diligência, têm sido alvo de muitas críticas, uma vez que desconsiderou as exigências de competência, formação teórica e experiência profissional que se exige atualmente de um administrador.
} 
contra as irregularidades que ocorre ram no processo de cisório. ${ }^{33}$ Grifamos

O Relator destacou ainda que se insere no dever de cuidado atribuído aos administradores da companhia monitorar, de forma permanente, o andamento geral dos negócios, exigindo-se uma vigilância especial quando diante de situações relevantes que demandem maior escrutínio por parte do administrador.

Cumpre ainda destacar que a diligência que se espera do administrador é a diligência ordinária ${ }^{34}$, não uma diligência excepcional e o padrão de diligência deve ser analisado caso a caso, levando-se em consideração as características da companhia, da decisão, do administrador, da informação, do tempo e dos recursos disponíveis. Nesse sentido, não devemos indagar qual a conduta mais diligente, mas sim se houve falta de diligência. ${ }^{3536}$

Os estudiosos do dever de diligência, tendem a subdividi-lo em outros deveres. Nelson Eiririk, Ariádna B. Gaal, Flávia Parente e Marcus de Freitas Henriques, por exemplo, subdividem esse dever em cinco principais deveres: (i) o dever de se qualificar para o exercício, (ii) o dever de bem administrar; (iii) o dever de se informar; (iv) o dever de investigar; e (iv) o dever de vigiar, e ainda assim destacam a fluidez ${ }^{37}$ de seu conceito.

\footnotetext{
${ }^{33}$ Disponível em: <http://www.cvm.gov.br/export/sites/cvm/noticias/anexos/2018/20180327 PAS CVM RJ20139266 Granos Granitos Voto DHM.pdf> Acesso em: 04 de mai. 2018.

34 ADAMEK, Marcelo Vieira Von. Op. cit., p. p. 125.

35 SAMPAIO CAMPOS, Luiz Antonio de. Op. cit., p. 802.

36 Ao analisar o PAS CVM RJ2013/9266, o relator adotou as palavras de Luiz Antônio de Sampaio Campos, no livro Direito das Companhias sobre o tema: "[n]ão existe, entretanto, uma única forma de atuar diligentemente (...), o que significa, por outras palavras, que, para fins de verificar o cumprimento desse dever por parte dos administradores, não se deve indagar qual a conduta mais diligente, mas, sim, se houve falta de diligência no comportamento adotado".

37 "Conforme reconhecido pela própria CVM, no julgamento do Processo Administrativo Sancionador CVM no RJ 2005/1443, em 10.05.2006, Rel. Dir. Pedro Oliva Marcilio de Sousa, a dificuldade de limitação da abrangência do atuar diligente do administrador também é observada no modo pelo qual a autarquia investiga e julga os processos administrativos por ela instaurados (...)”. EIZIRIK, Nelson; GAAL, Ariádna B.; PARENTE, Flávia; HENRIQUES, Marcus de Freitas, Op. cit, p. 427.
} 
Sobre o tema, a diretora relatora Norma Jonssen Parente destacou na sessão de julgamento do PAS CVM 03/1997, em 12 de agosto de 2004:

(...) a subjetividade e o caráter genérico, ínsitos à expressão "dever de diligência", acolhida pela lei, sãojustamente a garantia encontrada pelo ordenamento para a tutela dessa relação de confiança que, no caso de instituições financeiras, torna-se ainda mais aguda. Não se pode tolerar, portanto, que os conceitos jurídicos indeterminados, reflexos legislativos da pluralidade e da mutabilidade da sociedade contemporânea, tornem-se, por obra de sofismas e falácias, escusas para a não aplicação da lei. ${ }^{38}$

A ex-diretora da CVM, em seu livro, fixa, com base na jurisprudência brasileira e estrangeira, diversos padrões de conduta esperados do administrador probo. No caso de transações entre partes relacionadas, a adoção de tais padrões de comportamento tem importância fundamental para garantir o interesse da companhia. ${ }^{39}$

Por fim, se verifica que o dever de diligência deve ser observado em conjunto com os demais deveres estabelecidos pela legislação, podendo ser considerado um norte para a conduta do administrador, que deve sempre buscar o interesse da companhia. ${ }^{40}$

\section{2. $\quad$ Dever de lealdade}

No mesmo intuito de não esgotar os padrões de conduta do administrador, o art. 155 da Lei de Sociedades Anônimas ${ }^{41}$, estabelece um rol exemplificativo

38 Disponível em: <http://www.cvm.gov.br/export/sites/cvm/sancionadores/sancionador/anexos/ 2004/20040909 PAS 0397.pdf> Acesso em: 04 de mai. 2018.

${ }^{39}$ PARENTE, Norma Jonssen; coordenação CARVALHOSA, Modesto, Op. cit., p. 503.

40 PARENTE, Norma Jonssen; coordenação CARVALHOSA, Modesto, Ibid., p. 501.

41 Art. 155. O administrador deve servir com lealdade à companhia e manter reserva sobre os seus negócios, sendo-lhe vedado:

I - usar, em benefício próprio ou de outrem, com ou sem prejuízo para a companhia, as oportunidades comerciais de que tenha conhecimento em razão do exercício de seu cargo;

II - omitir-se no exercício ou proteção de direitos da companhia ou, visando à obtenção de vantagens, para si ou para outrem, deixar de aproveitar oportunidades de negócio de interesse da companhia; 
de condutas vedadas em atenção ao dever de lealdade (duty of loyalty). Em síntese, as normas extraídas do art. 155 da Lei de Sociedades Anônimas, impõe um dever ao administrador de não se aproveitar de oportunidades negociais decorrentes de sua gestão da companhia (duty not to usurp a corporate opportunity), bem como de não divulgar ou utilizar informações privilegiadas ${ }^{42}$.

Dentre as condutas vedadas pelo dever de lealdade, estão (i) usar, em benefício próprio ou de outrem, com ou sem prejuízo para a companhia, as oportunidades comerciais de que tenha conhecimento em razão do exercício de seu cargo; (ii) omitir-se no exercício ou proteção de direitos da companhia ou, visando à obtenção de vantagens, para si ou para outrem, deixar de aproveitar oportunidades de negócio de interesse da companhia; (iii) adquirir, para revender com lucro, bem ou direito que sabe necessário à companhia, ou que esta tencione adquirir e (iv) utilizar informação privilegiada buscando auferir vantagem.

No caso de transações entre partes relacionadas, os deveres negativos que são extraídos do dever de lealdade são muito importantes pois ao passo que vedam ao administrador o uso de oportunidades da companhia, asseguram, ou ao menos, aumentam as chances de que o administrador atue de acordo com o interesse social.

III - adquirir, para revender com lucro, bem ou direito que sabe necessário à companhia, ou que esta tencione adquirir.

$\S 1^{\circ}$ Cumpre, ademais, ao administrador de companhia aberta, guardar sigilo sobre qualquer informação que ainda não tenha sido divulgada para conhecimento do mercado, ob tida em razão do cargo e capaz de influir de modo ponderável na cotação de valores mobiliários, sendo-lhe vedado valer-se da informação para obter, para si ou para outrem, vantagem mediante compra ou venda de valores mobiliários.

$\S 2^{\circ} \mathrm{O}$ administrador deve zelar para que a violação do disposto no $\S 1^{\circ}$ não possa ocorrer através de subordinados ou terceiros de sua confiança.

$\S 3^{\circ}$ A pessoa prejudicada em compra e venda de valores mobiliários, contratada com infração do disposto nos $\S \S 1^{\circ} \mathrm{e} 2^{\circ}$, tem direito de haver do infrator indenização por perdas e danos, a menos que ao contratar já conhecesse a informação.

$\S 40$ É vedada a utilização de informação relevante ainda não divulgada, por qualquer pessoa que a ela tenha tido acesso, com a finalidade de auferir vantagem, para si ou para outrem, no mercado de valores mobiliários.

${ }^{42}$ A utilização de informação privilegiada ainda não divulgada ao público caracteriza a prática de Insider Trading. 
Em seu aspecto positivo, o dever de lealdade também é de grande importância para transações entre partes relacionadas. Com efeito, apesar de a Lei de Sociedades Anônimas prever o dever de lealdade do administrador para com a companhia, não se estendendo diretamente aos acionistas, há o entendimento de que existe um dever geral de lealdade societária. ${ }^{43}$

O parecer de orientação CVM n 35 , de $1^{\circ}$ de setembro de 2008 , que busca dar concretude aos deveres fiduciários dos administradores é esclarecedor ao tratar do tema:

O art. 154 da Lei ${ }^{\circ}$ 6.404, de 1976, prevê que o administrador deve exercer suas funções "para lograr os fins e no interesse da companhia", sendo-lhe vedado faltar a esse dever "para a defesa dos interesses dos que o elegeram". Da mesma forma, o art. 155 determina que o administrador deve "lealdade à companhia" e não a terceiros. Portanto, os administradores das controladas devem negociar as operações de fusão, incorporação e incorporação de ações em benefício de todos os seus acionistas e não apenas do controlador.

\subsection{Dever de informar}

O dever de informar (disclosure), previsto no art. 157 da Lei de Sociedades Anônimas ${ }^{44}$, pode ser visto como um desdobramento do dever de lealdade, e se destina apenas aos administradores de companhias abertas.

\footnotetext{
43 ADAMEK, Marcelo Vieira Von. Op. cit., p. 154.

44 Art. 157. O administrador de companhia aberta deve declarar, ao firmar o termo de posse, o número de ações, bônus de subscrição, opções de compra de ações e debêntures conversíveis em ações, de emis são da companhia e de sociedades controladas ou do mesmo grupo, de que seja titular. $\S 1^{\circ} \mathrm{O}$ administrador de companhia aberta é obrigado a revelar à as sembléia-geral ordinária, a pedido de acionistas que representem 5\% (cinco por cento) ou mais do capital social:

a) o número dos valores mobiliários de emissão da companhia ou de sociedades controladas, ou do mesmo grupo, que tiver adquirido ou alienado, diretamente ou através de outras pessoas, no exercício anterior;

b) as opções de compra de ações que tiver contratado ou exercido no exercício anterior;

c) os benefícios ou vantagens, indiretas ou complementares, que tenha recebido ou esteja recebendo da companhia e de sociedades coligadas, controladas ou do mesmo grupo;

d) as condições dos contratos de trabalho que tenham sido firmados pela companhia com os diretores e empregados de alto nível;

e) quaisquer atos ou fatos relevantes nas atividades da companhia.

$\S 2^{\circ}$ Os esclarecimentos prestados pelo administrador poderão, a pedido de qualquer acionista, ser reduzidos a escrito, autenticados pela mesa da as sembléia, e fornecidos por cópia aos solicitantes.
} 
Tal dever está regulamentado pela ICVM n 358/02 que tem um rol exemplificativo de fatos relevantes e enuncia "a obrigação de comunicar à bolsa de valores e à CVM e de divulgar pela imprensa todas as deliberações ou fato ocorridos que possam influir na cotação dos valores mobiliários de emissão da companhia. $45 " 46$

Apesar da norma não mencionar expressamente transações entre partes relacionadas como fato relevante, pela definição do próprio termo entende-se que há um dever de disclosure destas operações. Com efeito, como será demonstrado mais a frente, as instruções 480 e 481, de 2009 da CVM, enunciam o dever de comunicação de transações entre partes relacionadas relevantes.

No que tange ao cumprimento do dever de informar, José Edwaldo Tavares Borba $^{47}$ e Rodrigo Ferraz Pimenta da Cunha ${ }^{48}$ destacam seu possível conflito com o dever de sigilo. Com efeito, mais uma vez, o parâmetro para resolução do conflito, é atuar com lealdade, diligência e no interesse da companhia.

\footnotetext{
$\S 3^{\circ}$ A revelação dos atos ou fatos de que trata este artigo só poderá ser utilizada no legítimo interesse da companhia ou do acionista, respondendo os solicitantes pelos abusos que praticarem. $\S 4^{\circ}$ Os administradores da companhia aberta são obrigados a comunicar imediatamente à bolsa de valores e a divulgar pela imprensa qualquer deliberação da assembléia-geral ou dos órgãos de administração da companhia, ou fato relevante ocorrido nos seus negócios, que possa influir, de modo ponderável, na decisão dos investidores do mercado de vender ou comprar valores mobiliários emitidos pela companhia.

$\S 5^{\circ}$ Os administradores poderão recusar-se a prestar a informação ( $\$ 1^{\circ}$, alínea e), ou deixar de divulgála $\left(\S 4^{\circ}\right)$, se entenderem que sua revelação porá em risco interesse legítimo da companhia, cabendo à Comissão de Valores Mobiliários, a pedido dos administradores, de qualquer acionista, ou por iniciativa própria, decidir sobre a prestação de informação e responsabilizar os administradores, se for o caso . § 6o Os administradores da companhia aberta deverão informar imediatamente, nos termos e na forma determinados pela Comissão de Valores Mobiliários, a esta e às bolsas de valores ou entidades do mercado de balcão organizado nas quais os valores mobiliários de emissão da companhia estejam admitidos à negociação, as modificações em suas posições acionárias na companhia.

${ }^{45}$ Essa "Divulgação de Fato Relevante" encontra-se disciplinada pela Instrução CVM n 358/02, a qual, inclusive, arrola, exemplificativamente, vinte e duas modalidades de fato relevante.

${ }^{46}$ BORBA, José Edwaldo Tavares. Direito Societário, 13. Ed. rev. e atual. - Rio de Janeiro: Renovar, 2012. p. 431.

${ }^{47}$ Ibid., p. 432.

${ }^{48}$ Ibid., p. 255.
} 


\subsection{Conflito de interesses}

A sociedade anônima é ambiente de variados tipos de conflito de interesses entre administradores, acionistas e até mesmo terceiros. A análise da conduta do administrador na existência de conflito de interesses se mostra de grande importância no presente estudo dado o potencial conflito de interesses das transações entre partes relacionadas.

Além disso, no caso do Brasil, muitas vezes membros da administração da companhia também são acionistas. Nesses casos torna-se ainda mais complexa a verificação do conflito de interesses.

O conflito de interesses é analisado por grande parte da doutrina como matéria de fato a ser analisada no caso concreto $^{49}$. Isso porque, há o entendimento de que "só há relevância no conflito de interesses à medida que ele possa causar dano à companhia e lhe afetar a capacidade de atingir o seu objetivo mediante a exploração do objeto social" ${ }^{50}$.

Nesse sentido, Sampaio Campos enuncia na obra Direito das Companhias:

Para que se caracterize o conflito de interesses qualificado na LSA, é necessária uma situação que implique obrigatoriamente um choque de interesses, uma colisão entre o interesse social e o pessoal do administrador, que faria com que um não pudesse prevalecer sem o sacrifício do outro. Essa contraposição, esse conflito, deve ser substancial (e não apenas formal), efetivo e irreconciliável, a não permitir convergência ou conciliação. Para se alcançar um interesse, ter-se-ia inevitavelmente que prejudicar o outro. ${ }^{51}$

\footnotetext{
${ }^{49}$ Sobre o tema, Luiz Antonio de Sampaio Campos escreve: "Embora haja controvérsia sobre a extensão que se deva dar ao conteúdo da expressão conflito de interesses, a doutrina, de uma forma geral, tem se inclinado para estabelecer que o conflito de interesse é matéria de fato, que deve ser examinada em cada caso concreto, não sendo mesmo improvável que para situações teoricamente iguais ocorram, do ponto de vista da configuração do conflito de interesses, soluções diferentes". SAMPAIO CAMPOS, Luiz Antonio de. Op. cit., p. 840.

${ }^{50}$ Ibid., p. 841.

${ }^{51}$ Ibid., p. 840.
} 
No mesmo sentido, no entendimento de Francesco Galgano ${ }^{52}$, o conflito de interesses entre o administrador e a sociedade existe quando o administrador em determinada deliberação é portador de dúplice interesse: o social e o seu particular, não podendo um interesse ser satisfeito sem o sacrifício do outro.

Importante destacar que a arguição de conflito de interesses ocorre para proteger a transação de quaisquer danos decorrentes de decisão tomada em interesse diverso do da companhia. Com efeito, "se o dano, ainda que potencial, não se verifica, não há razão para se dizer que a atuação foi resultado de um conflito de interesses". ${ }^{3}$

Nesse sentido, Sampaio Campos defende que (i) a sanção à atuação conflitante ocorre na hipótese de conflito substancial de interesses, ou seja, quando a contratação não ocorre em condições razoáveis ou de mercado e (ii) a invalidade de transação conflituosa em que o conflito não foi advertido e que o administrador não deixou de atuar, como determina a própria lei, ocorre apenas se comprovado dano à companhia.

Para melhor entendimento da matéria, importante esclarecer a distinção entre conflito formal e substancial de interesses. Nas palavras de Nelson Eizirik, Ariádna B. Gal, Flávia Parente e Marcus de Freitas Henriques:

O conflito formal de interesses ou conflito de interesses latu sensué aquele existente em todo negócio jurídico bilateral ou unilateral, em que o acionista ou o administrador e a sociedade são partes contratantes.

(...) No conflito formal ou lato sensu, o impedimento da atuação do acionista ou administrador tem como fundamento a existência de uma relação contratual de natureza unilateral ou bilateral, envolvendo o acionista ou administrador e a sociedade.

Assim, sempre haverá conflito formal ainda que o negócio jurídico acarrete benefícios equitativos para a sociedade e para seu acionista ou administrador.

\footnotetext{
52 GALGANO, Francesco. Tratado do conflito de interesses entre acionista e companhia, "La Società per Azioni". In Trattato di Diritto Commerciale e di Diritto Pubblico dell'Economia, v. 7 Padova, CEDAM, 1984, p. 230.

${ }^{53}$ CAMPOS, Luiz Antonio de Sampaio, Op. cit., p. 841.
} 
Haverá, por outro lado, conflito substancial de interesses ou conflito de interesses stricto sensu, quando o voto for utilizado com desvio de finalidade, para promover interesses do administrador ou do controlador incompatíveis com o interesse social. ${ }^{54}$

Não obstante o entendimento de parte da doutrina pela adoção do conflito substancial de interesses, o art. $156^{55}$ da Lei de Sociedades Anônimas não conceitua conflito de interesses, mas apenas estabelece algumas orientações para o tratamento da matéria.

A norma emanada do art. 156 determina que presente o conflito de interesses, é vedada (i) a atuação do administrador na operação social com interesse conflitante, e (ii) a participação do administrador em deliberações sociais sobre matérias relacionadas ao conflito em referência.

No entendimento de Sampaio Campos na obra o Direito da Companhias, o administrador, em caso de conflito de interesses, tem os deveres de (i) não intervir em Operação Social; (ii) não intervir em Deliberação; e (iii) comunicar a existência de conflito. ${ }^{56}$

(i) Dever de não intervir em Operação Social: é dever do administrador não intervir como representante da companhia em operação envolvendo companhia e administrador, em que se verifica conflito de interesse. Não há vedação para que o administrador atue como representante de seus próprios interesse, há apenas algumas limitações na

\footnotetext{
${ }^{54}$ EIZIRIK, Nelson; GAAL, Ariádna B.; PARENTE, Flávia; HENRIQUES, Marcus de Freitas, Op. cit, p. 469.

55 Art. 156. É vedado ao administrador intervir em qualquer operação social em que tiver interesse conflitante com o da companhia, bem como na deliberação que a respeito tomarem os demais administradores, cumprindo-lhe cientificá-los do seu impedimento e fazer consignar, em ata de reunião do conselho de administração ou da diretoria, a natureza e extensão do seu interesse.

$\S 1^{\circ}$. Ainda que observado o disposto neste artigo, o administrador somente pode contratar com a companhia em condições razoáveis ou eqüitativas, idênticas às que prevalecem no mercado ou em que a companhia contrataria com terceiros.

$\S 2^{\circ}$. O negócio contratado com infração do disposto no $\S 1^{\circ}$ é anulável, e o administrador interessado será obrigado a transferir para a companhia as vantagens que dele tiver auferido.

${ }^{56}$ SAMPAIO CAMPOS, Luiz Antonio de. Op. cit., p. 843-846.
} 
sua atuação que deve pautar-se em condições de mercado, conforme enuncia o art. 156, $\S 1^{\circ}$ da Lei de Sociedades Anônimas.

(ii) Dever de não intervir em Deliberação: é dever do administrador não intervir em deliberações da sociedade que versem sobre matérias relacionadas ao conflito de interesses em questão. Sobre o tema, o autor entende que, "a extensão que se deve dar à vedação à intervenção do administrador em conflito de interesses na deliberação social deve ser restrita à proibição de discutir a matéria e proferir voto. Poderá ele prestar esclarecimentos e estar presente na deliberação específica. ” Não obstante, se os membros do órgão deliberativo "considerarem que a presença do administrador em conflito de interesses não é conveniente, poderão solicitar que se retire do recinto para a tomada da deliberação". 57

Ainda sobre o dever de não intervir em deliberação, discute-se se o administrador que não tenha intervindo em determinada deliberação conflitante, poderá executar o ato aprovado por aqueles que não possuem interesse conflitante.

(iii) Dever de comunicação da existência de conflito de interesses: É dever do administrador que possuir interesse conflitante com o da companhia, cientificar aos demais administradores do seu impedimento e consignar, em ata de reunião do conselho de administração ou da diretoria, a natureza e extensão do seu interesse ${ }^{58}$.

57 Ibid., p. 844.

58 À esse respeito, Sampaio Campos enuncia: "Não é suficiente a informação genérica do administrador de que está em conflito de interesse; a LSA impõe-lhe a obrigação de registrar a natureza e a extensão de seu interesse. Cabe ao administrador indicar a razão do conflito, o tipo de relação com a contraparte. Conforme ficou estabelecido pela corte inglesa: "um sujeito declara seu interesse não quando afirma que possui um interesse, mas quando afirma qual é seu interesse" (Liquidators of Imperial Mercantile Credit Association v. Coleman)”. SAMPAIO CAMPOS, Luiz Antonio de. Op. cit., p. 845. 
Nas palavras do advogado, "exige-se, portanto do administrador, um exame de consciência para indagar se há um conflito de interesse, pois, nessa hipótese, deverá ele informar aos administradores da companhia". ${ }^{59}$

Nesse ponto, apesar de os ensinamentos supracitados suscitarem a ideia de que o conflito de interesse deve ser substancial, questiona-se se para cumprir com os deveres acima enunciados não seria necessária uma análise à priori $\mathrm{e}$ formal do próprio administrador sobre a existência de conflito de interesses com a companhia para que caso seja verificado o conflito, o administrador adote as condutas acima descritas.

Nelson Eizirik, Ariádna B. Gal, Flávia Parente e Marcus de Freitas Henriques, entendem que assim como nos Estados Unidos, no Brasil, o conflito formal de interesses não é suficiente para determinar o impedimento de voto do administrador, sendo necessária análise substancial da matéria, uma vez que a ilicitude do seu ato ocorre apenas se este não atender ao interesse da companhia. ${ }^{60}$

Sendo assim:

(...) na medida em que eventual existência do conflito de intereses não deve ser verificada a priori, mas depende da análise do mérito da ope ração, pode-se afirmar que o administrador está, inclusive, autorizado a participar de deliberações sobre contratos que ele pessoalmente, tenha intenção de celebrar com a sociedade, desde que o negócio esteja em consonância com o interesse social e que haja transparência e lealdade na contratação" ${ }^{61}$.

Caso o administrador verifique interesse conflitante com o interesse social da companhia, os autores supracitados sustentam que esse "deve se abster

\footnotetext{
${ }^{59}$ Ibid., p. 845.

${ }^{60}$ No mesmo sentido, Sampaio Campos entende que "não é qualquer conflito de intereses que torna o negócio anulável, mas apenas aquele em que se verifica o prejuízo da companhia e o favorecimento em razão do conflito de interesses" Ibid., p. 847.

${ }^{61}$ EIZIRIK, Nelson; GAAL, Ariádna B.; PARENTE, Flávia; HENRIQUES, Marcus de Freitas, Op. cit., p. 475.
} 
de participar da deliberação a ser tomada, cientificar os demais administradores e fazer constar da ata de seu impedimento". ${ }^{62}$.

Para Sampaio Campos, em caso de interesse conflitante com o da companhia terá o administrador o ônus de contratar em condição de mercado, equitativa e razoável. In verbis

Desse preceito decorre que o administrador da companhia, mesmo estando na outra ponta da operação e declaradamente representando exclusivamente o seu interesse individual, e não o da companhia, que será representada por outros administradores, não se desvincula totalmente da sua condição de administrador e, por isso, the é imposto esse ônus adicional, que não é imposto a qualquer terceiro, qual seja, o de contratar em condição razoável e equitativa.

(...) $\mathrm{O}$ administrador que não interveio na operação social e na respectiva deliberação deve, contudo, se abster de contratar com a companhia se perceber que as condições da contratação são prejudiciais à sociedade, à medida que não sejam equitativas ou razoáveis, ou que sejam diferentes daquelas em que a companhia contrataria com terceiros ou fora de condições de mercado. ${ }^{63}$

Na jurisprudência norte americana, se verifica um tratamento semelhante no que concerne ao conflito de interesses, uma vez que se admite contratação entre a companhia e o administrador, "desde que ela seja fair ou que seja aprovada pela maioria dos acionistas, uma vez que adequadamente informados". 64

Esse nem sempre é o entendimento da CVM que, ao analisar o conflito de interesses em transações entre partes relacionadas, no julgamento do PAS CVM n ${ }^{\circ}$ RJ-2012-3110, julgado em 2017, condenou, com base no art. 11, II, da Lei $\mathrm{n}^{\circ}$ Lei $\mathrm{n}^{\circ} 6.385$ de 1976 , o administrador à penalidade pecuniária no valor de $\mathrm{R} \$ 500.000,00$ (quinhentos mil reais), por ter representado a Companhia na contratação de sociedade da qual o seu filho era o principal cotista, infringindo assim o art. 156 da Lei de Sociedades Anônimas.

\footnotetext{
62 Ibid., p. 477.

${ }^{63}$ Ibid., p. 846.

${ }^{64}$ Ibid., p. 478.
} 
Quando do julgamento, a comissão deixou claro a adoção do critério formal para análise do conflito de interesses em transações entre partes relacionadas. In verbis:

(...) em março de 2004, já prevalecia nesta Autarquia o entendimento de que o art. 156 impede o administrador de atuar na operação na qual tenha interesse oposto ou paralelo ao interesse social, capaz de colocar em xeque a sua independência para negociar ou apreciar os termos da operação em nome da companhia. Vale dizer que, independentemente do exame do mérito da operação, tal administrador deve abster-se de intervir na condução da operação.

41. Tal interpretação foi acolhida pelo Colegiado da CVM no julgamento do PAS CVM n ${ }^{\circ} 32 / 2000$, ocorrido em 10.2010.2000, tendo sido consignado, na oportunidade, que "[n]ão se exige, a meu ver, para a violação da regra do art. 156 da Lei das S.A., ao menos no campo da respons abilidade administrativa, que a companhia experimente um prejuízo, sendo suficiente que a independência e o distanciamento do administrador estejam $\underline{\operatorname{afetados}}(\ldots) .{ }^{65}$ (Grifado)

A Comissão ressaltou a importância de utilizar como parâmetro de avaliação a análise de:

(...) se a transação foi efetuada em condições semelhantes às que seriam aplicadas entre partes não relacionadas (quanto a preços, prazos, encargos, qualidade etc.) que contratassem com base em sua livre vontade e em seu melhor interesse. ${ }^{66}$

Ao analisar a responsabilidade do administrador ao contratar com sociedade, em que seu filho era principal cotista, não foi possível identificar a comutatividade da transação ante a insuficiência de provas.

No entanto, ao se analisar, no mesmo caso, a responsabilidade do administrador ao contratar com outra sociedade em que ele próprio era o principal cotista, apesar de condenado por infração ao art. 156, da Lei de

\footnotetext{
${ }^{65}$ PAS CVM n ${ }^{\circ}$ RJ-2012-3110, julgado em 2017. Disponível em: <2018http://www.cvm.gov.br/export/sites/cvm/s ancionadores/s ancionador/anexos/2017/RJ20123110_ Cia_Alianca_da_Bahia.pdf > Acessoem: 06 de mai. de 2018

${ }^{66}$ Idem.
} 
Sociedades Anônimas, a CVM considerou na dosimetria da pena do administrador o fato de que "o acusado logrou trazer elementos significativos acerca da comutatividade da transação". ${ }^{67}$

Se percebe que há uma grande divergência quanto ao dever dos administradores de abstenção de contratar com a companhia, nos termos do art. 156 da Lei de Sociedades Anônimas. No entanto, se verifica uma concordância no sentido de que na análise de transações entre partes relacionadas, deve ser observado se a contratação ocorreu em condição razoável e equitativa.

Por fim, se destaca que de acordo com a lei, a transação celebrada pelo administrador com interesse conflitante é anulável. Sobre o tema, parte da doutrina entende que "não é qualquer conflito de interesses que torna o negócio anulável, mas apenas aquele em que se verifica o prejuízo da companhia e o favorecimento em razão do conflito de interesses" ${ }^{98}$.

\subsection{Deveres dos administradores decorrentes de soft laws}

Conforme adiantado no início do capítulo, a Lei de Sociedades Anônimas, apesar de não enunciar a expressão transações entre partes relacionadas, estabelece em seu art. 245 que:

Os administradores não podem, em prejuízo da companhia, favorecer sociedade coligada, controladora ou controlada, cumprindo-lhes zelar para que as operações entre as sociedades, se houver, observem condições estritamente comutativas, ou com pagamento compensatório adequado; e respondem perante a companhia pelas perdas e danos resultantes de atos praticados com infração ao disposto neste artigo.

\footnotetext{
${ }^{67}$ PAS CVM n ${ }^{\circ} \mathrm{RJ}-2012-3110$, julgado em 2017. Dis ponível em: <2018http://www.cvm.gov.br/export/sites/cvm/sancionadores/sancionador/anexos/2017/RJ20123110_ Cia_Alianca_da_Bahia.pdf > Acessoem: 06 de mai. de 2018

${ }^{68}$ SAMPAIO CAMPOS, Luiz Antonio de. Op. cit., p. 847.
} 
Além disso, traz algumas normas que podem ser aplicadas a depender de como a transação se caracteriza. Por exemplo, caso se verifique abuso de poder ou conflito de interesses na transação, aplicam-se os dispositivos da lei para o tema ${ }^{69}$. Os diversos dispositivos que regulamentam os deveres dos administradores auxiliam que tais transações sejam feitas no interesse da companhia.

A recente Lei $\mathrm{n}^{\circ} 13.506$, de 13 de novembro de 2017, que dispõe sobre o processo administrativo sancionador na esfera de atuação do Banco Central do Brasil e da Comissão de Valores Mobiliários, em que pese tenha conceituado transações entre partes relacionadas, o fez alterando a redação do art. $34^{70}$ da Lei

69 "Nos termos dos artigos 153 a 156 da Lei n ${ }^{\circ}$ 6.404/76, os administradores devem conduzir os negócios sociais com diligência e lealdade, abstendo-se de interferir em operações nas quais possuamconflito de interesses. O artigo 245 prevê ainda que os administradores devem zelar para que as operações entre a companhia e suas coligadas, controladas e controladoras observem condições comutativas ou com pagamento compensatório adequado". Ofício-Circular CVM/SEP, de 28 de fevereiro de 2018.

70 Art. 34. É vedado às instituições financeiras realizar operação de crédito com a parte relacionada. (Redação dada pela Lei $n^{\circ} 13.506$, de 2017)

(...)

§ 3o Considera-se parte relacionada à instituição financeira, para efeitos deste artigo: (Incluído pela Lei $\mathrm{n}^{\circ}$ 13.506, de 2017)

I - seus controladores, pessoas físicas ou jurídicas, nos termos do art. 116 da Lei no 6.404, de 15 de dezembro de 1976; (Incluído pela Lei no 13.506, de 2017)

II - seus diretores e membros de órgãos estatutários ou contratuais; (Incluído pela Lei $\mathrm{n}^{\circ}$ 13.506, de 2017) III - o cônjuge, o companheiro e os parentes, consanguíneos ou afins, até o segundo grau, das pessoas mencionadas nos incisos I e II deste parágrafo; (Incluído pela Lei $\mathrm{n}^{\circ} 13.506$, de 2017)

IV - as pessoas físicas com participação societária qualificada em seu capital; e (Incluído pela Lei ${ }^{\circ}$ 13.506, de 2017)

V - as pessoas jurídicas: (Incluído pela Lei $\mathrm{n}^{\circ} 13.506$, de 2017)

a) com participação qualificada em seu capital; (Incluído pela Lei $\mathrm{n}^{\circ} 13.506$, de 2017)

b) em cujo capital, direta ou indiretamente, haja participação societária qualificada; (Incluído pela Lei $\mathrm{n}^{\circ}$ 13.506, de 2017)

c) nas quais haja controle operacional efetivo ou preponderância nas deliberações, independentemente da participação societária; e (Incluído pela Lei no 13.506, de 2017)

d) que possuírem diretor ou membro de conselho de administração em comum. (Incluído pela Lei ${ }^{\circ}$ 13.506, de 2017)

$\S 4^{\circ}$. Excetuam-se da vedação de que trata o caput deste artigo, respeitados os limites e as condições estabelecidos em regulamentação: (Incluído pela Lei n ${ }^{\circ} 13.506$, de 2017)

I - as operações realizadas em condições compatíveis com as de mercado, inclusive quanto a limites, taxas de juros, carência, prazos, garantias requeridas e critérios para classificação de risco para fins de constituição de provisão para perdas prováveis e baixa como prejuízo, sem benefícios adicionais ou diferenciados comparativamente às operações deferidas aos demais clientes de mesmo perfil das respectivas instituições; (Incluído pela Lei no 13.506, de 2017)

II - as operações com empresas controladas pela União, no caso das instituições financeiras públicas federais; (Incluído pela Lei nº 13.506, de 2017) 
no 4.595, de 31 de dezembro de 1964, que dispõe sobre a Política e as Instituições Monetárias, Bancárias e Creditícias, e cria o Conselho Monetário Nacional.

Não obstante, as transações entre partes relacionadas foram expressamente regulamentadas pela Comissão de Valores Mobiliários, bem como por diferentes códigos de auto regulação. No que tange a regulamentação da CVM, se destaca que o art. 11 da Lei do Mercado de Valores Mobiliários assegura à comissão a imposição de penalidades - isoladas ou cumulativamente - aos infratores da Lei de Sociedades Anônimas ou de outrasnormas legais cujo cumprimento lhe caiba fiscalizar.

\subsubsection{Comissão de Valores Mobiliários (CVM)}

\section{A) Instruções e Deliberações da CVM}

Inicialmente, cumpre destacar, que a CVM em um primeiro momento não definiu Transações entre Partes Relacionadas, adotando a definição das "regras contábeis que tratam desse assunto". Tais expressões foram melhores definidas em 2010 quando aprovada a Deliberação n 642 da CVM, que aprovou o Pronunciamento Técnico CPC 05(R1) do Comitê de Pronunciamentos Contábeis - CPC sobre divulgação de partes relacionadas.

Tal documento definiu Transação com parte relacionada como "a transferência de recursos, serviços ou obrigações entre uma entidade que reporta

III - as operações de crédito que tenham como contraparte instituição financeira integrante do mes mo conglomerado prudencial, desde que contenham cláusula contratual de subordinação, observado o disposto no inciso V do art. 10 desta Lei, no caso das instituições financeiras bancárias; (Incluído pela Lei $\mathrm{n}^{\circ} 13.506$, de 2017)

IV - os depósitos interfinanceiros regulados na forma do inciso XXXII do caput do art. 4o desta Lei; (Incluído pela Lei $\mathrm{n}^{\circ} 13.506$, de 2017)

V - as obrigações assumidas entre partes relacionadas em decorrência de responsabilidade imposta a membros de compens ação e demais participantes de câmaras ou prestadores de serviços de compensação e de liquidação autorizados pelo Banco Central do Brasil ou pela Comissão de Valores Mobiliários e suas respectivas contrapartes em operações conduzidas no âmbito das referidas câmaras ou prestadores de serviços; e (Incluído pela Lei n 13.506, de 2017) 
a informação a uma parte relacionada independentemente de ser cobrado um preço em contrapartida". 71

No que se refere à Deliberação da CVM nº 642 de 2010, importante entender a definição dada ao termo influência significativa. Nos termos do art. 243, $\S 4^{\circ}$ e $5^{\circ}$ da Lei de Sociedades Anônimas: “(...) considera-se que há influência significativa quando a investidora detém ou exerce o poder de participar nas decisões das políticas financeira ou operacional da investida, sem controlá-la" e "é presumida influência significativa quando a investidora for titular de $20 \%$ (vinte por cento) ou mais do capital votante da investida, sem controlá-la”.

Antes de editar a deliberação $n^{\circ} 642$ de 2010, a CVM já tratava do tema no art. 31-D da ICVM n 308, de 14 de maio de 1999, que atribui expressamente ao Comitê de Auditoria Estatutário a competência para "avaliar e monitorar,

${ }^{71}$ Parte relacionada é a pessoa ou a entidade que está relacionada com a entidade que está elaborando suas demonstrações contábeis (neste Pronunciamento Técnico, tratada como "entidade que reporta a informação").

(a) Uma pessoa, ou um membro próximo de sua família, está relacionada com a entidade que reporta a informação se:

(i) tiver o controle pleno ou compartilhado da entidade que reporta a informação;

(ii) tiver influência significativa sobre a entidade que reporta a informação; ou

(iii) for membro do pessoal chave da administração da entidade que reporta a informação ou da controladora da entidade que reporta a informação.

(b) Uma entidade está relacionada com a entidade que reporta a informação se qualquer das condições abaixo for observada:

(i) a entidade e a entidade que reporta a informação são membros do mesmo grupo econômico (o que significa dizer que a controladora e cada controlada são inter-relacionadas, bem como as entidades sob controle comum são relacionadas entre si);

(ii) a entidade é coligada ou controlada em conjunto (joint venture) de outra entidade (ou coligada ou controlada em conjunto de entidade membro de grupo econômico do qual a outra entidade é membro);

(iii) ambas as entidades estão sob o controle conjunto (joint ventures) de uma terceira entidade;

(iv) uma entidade está sob o controle conjunto (joint venture) de uma terceira entidade e a outra entidade for coligada dess a terceira entidade;

(v) a entidade é um plano de benefício pós-emprego cujos beneficiários são os empregados de ambas as entidades, a que reporta a informação e a que está relacionada com a que reporta a informação. Se a entidade que reporta a informação for ela própria um plano de benefício pós -emprego, os empregados que contribuem com a mesma serão também considerados partes relacionadas com a entidade que reporta a informação;

(vi) a entidade é controlada, de modo pleno ou sob controle conjunto, por uma pessoa identificada na letra (a);

(vii) uma pessoa identificada na letra (a)(i) tem influência significativa sobre a entidade, ou for membro do pessoal chave da administração da entidade (ou de controladora da entidade). 
juntamente com a administração e a área de auditoria a adequação das transações com partes relacionadas realizadas pela companhia e suas respectivas evidenciações". 72

Por meio de regulação aplicável às companhias abertas, a CVM institui com as Instruções CVM n 480, de 7 de dezembro de 2009 e 481, de 17 de dezembro de 2009, alguns deveres de prestação de informações ao mercado na ocorrência de determinadas operações com partes relacionadas.

A ICVM n ${ }^{\circ} 480$, de 7 de dezembro de 2009, determina, que o emissor deve enviar à CVM, por meio de sistema eletrônico informações sobre eventuais transações entre partes relacionadas em até sete dias úteis a contar da ocorrência.

Em junho de 2017, a redação do item 16.1 do Anexo 24 de referida norma foi atualizada e se passou a exigir ao descrever "as regras, políticas e práticas do emissor quanto à realização de transações com partes relacionadas", a descrição do órgão responsável por sua aprovação, data da aprovação, bem como, caso o emissor divulgue a política, locais onde o documento pode ser consultado.

O item 16.2 da mesma instrução determina que, em regra, devem ser divulgadas nas demonstrações financeiras individuais ou consolidadas do emissor e que tenham sido celebradas no último exercício social ou estejam em vigor no exercício social corrente, informações como: (i) nome das partes relacionadas (ii) relação das partes com o emissor; (iii) data da transação; (iv) objeto do contrato; (v) se o emissoré credor ou devedor; (vi) montante envolvido no negócio; (v) saldo existente e (vi) montante correspondente ao interesse de tal parte relacionada no negócio, se for possível aferir.

Destaca-se também na ICVM $n^{\circ} 480$, de 7 de setembro de 2009, o item 29, que determina que "a companhia deve ter políticas e práticas de governança visando a assegurar que toda e qualquer transação com parte relacionada seja

${ }^{72}$ ICVM n 308, de 14 de maio de 1999. 
realizada sempre no melhor interesse da companhia, com plena independência e absoluta transparência".

Dentre as medidas a serem adotas, estão que (i) o estatuto social deve definir quais transações com partes relacionadas devem ser aprovadas pelo conselho de administração, com a exclusão de eventuais membros com interesses potencialmente conflitantes; (ii) o conselho de administração deve aprovar e implementar uma política de transações com partes relacionadas ${ }^{73}$; (iii) no caso da não adoção das práticas recomendadas ou da sua adoção de forma parcial, deve ser apresentada a justificativa do emissor sobre o assunto; (iv) no caso da indicação da adoção das práticas, deve ser informado, em linha com as orientações do Código, como o emissor implementa e verifica a adoção desses procedimentos.

Outro tratamento importante ocorre quando a transação entre partes relacionadas for um empréstimo ou outro tipo de dívida. Nesses casos, a norma destaca a importância de que se informe também (i) a natureza e as razões para a operação e (ii) a taxa de juros cobrada.

\section{B) Ofício-Circular CVM/SEP, de 28 de fevereiro de 2018}

O Ofício-Circular CVM/SEP, de 28 de fevereiro de 2018 que estabelece orientações gerais sobre procedimentos a serem observados pelas companhias abertas, estrangeiras e incentivadas, reforça a observância das normas

\footnotetext{
73 Dentre outras regras, tal política deve incluir: “(i) previsão de que, previamente à aprovação de trans ações es pecíficas ou diretrizes para a contratação de transações, o conselho de adminis tração solicite à diretoria alternativas de mercado à transação com partes relacionadas em questão, ajustadas pelos fatores de risco envolvidos; (ii) vedação a formas de remuneração de assessores, consultores ou intermediários que gerem conflito de interes ses com a companhia, os administradores, os acionistas ou classes de acionistas; (iii) proibição a emprés timos em favor do controlador e dos administradores ; (iv) as hipóteses de transações com partes relacionadas que devem ser embasadas por laudos de avaliação independentes, elaborados sem a participação de nenhuma parte envolvida na operação em questão, seja ela banco, advogado, empresa de consultoria especializada, entre outros, com base em premissas realistas e informações referendadas por terceiros; (v) que reestruturações societárias envolvendo partes relacionadas devem assegurar tratamento equitativo para todos os acionistas" (grifou-se)
} 
supracitadas. Enuncia ainda que não é possível estabelecer, a priori, uma lista exaustiva de quais seriam os principais termos e condições a serem destacados na comunicação de transações entre partes relacionadas.

Não obstante, destaca que o objetivo de tal comunicação "é permitir que o investidor conheça e, assim, monitore as transações relevantes realizadas pela companhia com partes relacionadas". ${ }^{74}$ Consequentemente, a partir dessas informações o investidor poderá avaliar se a transação foi tomada no melhor interesse da companhia.

\section{C) Parecer de orientação CVM no 35, de 1ํ de setembro de 2008}

O Parecer de orientação CVM $\mathrm{n}^{\circ} 35$, de 2008, confere tratamento diferenciado aos deveres fiduciários dos administradores nas operações de fusão, incorporação e incorporação de ações envolvendo sociedade controladora e suas controladas ou sociedades sob controle comum.

$\mathrm{O}$ documento reconhece o risco de que essas operações não sejam comutativas, e corrobora o entendimento da CVM de que o regime especial

${ }^{74}$ Ofício-Circular CVM/SEP, de 28 de fevereiro de 2018 
previsto no art. $264^{75}$ não afasta a aplicação dos arts. $153,154,155$ e 245 da Lei de Sociedades Anônimas. 76

Se observa que a obrigação de não atuar em caso de conflito de interesses não está no rol de deveres fiduciários do administrador nas operações tratadas no parecer. Com efeito, caso empregada a teoria do conflito formal de interesses, sobre tais operação muitas vezes essas seriam inviabilizadas.

A CVM afirma ainda, que os administradores ao negociar o protocolo ${ }^{77}$, devem cumprir os deveres fiduciários que a lei lhes atribui, defendendo os interesses da companhia que administram e de seus acionistas, assegurando a fixação de uma relação de troca equitativa.

Com efeito, o parecer (i) estabelece diretrizes ${ }^{78}$ orientando os administradores de companhias abertas a respeito de procedimentos a serem

\footnotetext{
75 Art. 264. Na incorporação, pela controladora, de companhia controlada, a justificação, apresentada à as sembléia-geral da controlada, deverá conter, além das informações previstas nos arts. 224 e 225 , o cálculo das relações de substituição das ações dos acionistas não controladores da controlada com base no valor do patrimônio líquido das ações da controladora e da controlada, avaliados os dois patrimônios segundo os mesmos critérios e na mesma data, a preços de mercado, ou com base em outro critério aceito pela Comissão de Valores Mobiliários, no caso de companhias abertas.

§ 1 A avaliação dos dois patrimônios será feita por 3 (três) peritos ou empresa especializada e, no caso de companhias abertas, por empresa especializada.

$\S 2$ 2 - Para efeito da comparação referida neste artigo, as ações do capital da controlada de propriedade da controladora serão avaliadas, no patrimônio desta, em conformidade com o dis posto no caput.

$\S 3^{\circ}$ Se as relações de substituição das ações dos acionis tas não controladores, previs tas no protocolo da incorporação, forem menos vantajosas que as resultantes da comparação prevista neste artigo, os acionistas dissidentes da deliberação da assembléia-geral da controlada que aprovar a operação, observado o dis posto nos arts. 137, II, e 230, poderão optar entre o valor de reembolso fixado nos termos do art. 45 e o valor do patrimônio líquido a preços de mercado

$\S 40$ Aplicam-se as normas previstas neste artigo à incorporação de controladora por sua controlada, à fusão de companhia controladora com a controlada, à incorporação de ações de companhia controlada ou controladora, à incorporação, fusão e incorporação de ações de sociedades sob controle comum. $\S 5^{\circ} \mathrm{O}$ disposto neste artigo não se aplica no caso de as ações do capital da controlada terem sido adquiridas no pregão da bolsa de valores ou mediante oferta pública nos termos dos artigos 257 a 263.

76 Ao negociar uma operação de fusão, incorporação ou incorporação de ações, os administradores devem agir com diligência e lealdade à companhia que administram, zelando para que a relação de troca e demais condições do negócio observem condições estritamente comutativas.

77 Os administradores da companhia controlada, ou de ambas as companhias sob controle comum, têm a função negociar o protocolo de incorporação ou fusão que será submetido à aprovação da assembléia geral.

${ }^{78}$ Dentre as diretrizes estão:

(i) os administradores das controladas devem negociar as operações de fusão, incorporação e incorporação de ações em benefício de todos os seus acionistas e não apenas do controlador (art. 154).
} 


\title{
seguidos nas operações objeto do parecer e (ii) enuncia os procedimentos ${ }^{79}$ que
}

\section{devem ser adotados para assegurar a comutatividade da transação.}

\author{
Dentre os procedimentos sugeridos, se destacam as recomendações de
} constituição de um comitê especial ${ }^{80}$ independente $^{81}$ para negociar a operação e submeter suas recomendações ao conselho de administração; ou que a operação

(ii) os administradores das controladas devem negociar as operações de fusão, incorporação e incorporação de ações com a mesma prudência, cautela e, sobretudo, empenho que negociariam uma operação similar envolvendo uma empresa da qual foss em os únicos proprietários. (art. 153)

(iii) os administradores devem negociar uma relação de troca de ações equiitativa para os acionistas de ambas as companhias, refletindo o valor de cada uma delas e repartindo entre elas os potenciais ganhos obtidos com a operação. (art. 245)

${ }^{79}$ Dentre os procedimentos estão:

i) a relação de troca e demais termos e condições da operação devem ser objeto de negociações efetivas entre as partes na operação;

ii) o início das negociações deve ser divulgado ao mercado imediatamente, como fato relevante, a menos que o interes se social exija que a operação seja mantida em sigilo;

iii) os administradores devem buscar negociar a melhor relação de troca e os melhores termos e condições possíveis para os acionistas da companhia;

iv) os administradores devem obter todas as informações necessárias para desempenhar sua função;

v) os adminis tradores devem ter tempo suficiente para desempenhar sua função;

vi) as deliberações e negociações devem ser devidamente documentadas, para posterior averiguação;

vii) os administradores devem considerar a neces sidade ou conveniência de contratar as sessores jurídicos e financeiros;

viii) os administradores devem se assegurar de que os assessores contratados sejam independentes em relação ao controlador e remunerados adequadamente, pela companhia;

ix) os trabalhos dos assessores contratados devem ser devidamente supervisionados;

$\mathrm{x})$ eventuais avaliações produzidas pelos assessores devem ser devidamente fundamentadas e os respectivos critérios, especificados;

xi) os adminis tradores devem considerar a possibilidade de adoção de formas alternativas para conclusão da operação, como ofertas de aquisição ou de permuta de ações;

xii) os administradores devem rejeitar a operação caso a relação de troca e os demais termos e condições propostos sejam insatisfatórios;

xiii) a decisão final dos administradores sobre a matéria, depois de analisá-la com lealdade à companhia e com a diligência exigida pela lei, deve ser devidamente fundamentada e documentada; e

xiv) todos os documentos que embasaram a decisão dos administradores devem ser colocados à disposição dos acionistas, na forma do art. $3^{\circ}$ da Instrução CVM n 319, de 3 de dezembro de 1999.

${ }^{80} \mathrm{Na}$ formação do comitê especial independente acima referido, a CVM recomenda a adoção de uma das seguintes alternativas:

i) comitê composto exclusivamente por administradores da companhia, em sua maioria independentes; ii) comitê composto por não-administradores da companhia, todos independentes e com notória capacidade técnica, desde que o comitê esteja previsto no estatuto, para os fins do art. 160 da Lei $\mathrm{n}^{\circ}$ 6.404, de 1976; ou

ii) comitê composto por: (a) um adminis trador escolhido pela maioria do conselho de adminis tração; (b) um conselheiro eleito pelos acionistas não-controladores; e (c) um terceiro, administrador ou não, escolhido em conjunto pelos outros dois membros.

${ }^{81}$ A independência dos membros do comitê es pecial não pode ser determinada de antemão, devendo ser examinada a cada caso. De qualquer modo, a CVM presumirá a independência, salvo demonstração em contrário, de pessoas que atendam à definição de "conselheiro independente" prevista no Regulamento do Novo Mercado da Bolsa de Valores de São Paulo. 
seja condicionada à aprovação da maioria dos acionistas não-controladores, inclusive os titulares de ações sem direito a voto ou com voto restrito.

A criação do comitê, em tese, possibilita a descentralização e independência do poder decisório, reservando parte da negociação da operação a um órgão autônomo. No entanto, nem sempre a existência formal desse comitê garante a independência necessária para análise da transação. ${ }^{82}$

Em 2012, por exemplo, a Suprema Corte de Delaware, ao analisar uma transação entre partes relacionadas - inobstante a existência do comitê especial com diretores independentes - confirmou uma decisão da Corte de Chancery e determinou que o acionista controlador e seus diretores pagassem mais de dois bilhões de dólares por violação aos seus deveres fiduciários. ${ }^{83}$

A decisão destacou que os diretores e administradores devem proporcionar real poder de barganha ao comitê especial e permitir a exploração de alternativas à proposta da parte relacionada. Além disso, afirmou que o comitê deve atuar como um negociador independente para alcançar o melhor negócio possível para a companhia e seus acionistas.

\subsubsection{Instituto Brasileiro de Governança Corporativa (IBGC)}

A $4^{\text {a }}$ Carta Diretriz do Instituto Brasileiro de Governança Corporativa ${ }^{84}$, publicada em 2014, tem como tema Transações entre Partes Relacionadas e enuncia como deveres dos Sócios e Administradores a lealdade, a independência, a diligência e a comutatividade.

No caso de grupos econômicos, a carta sugere que "a individualidade de cada sociedade deve ser estritamente observada. Seus administradores têm por

\footnotetext{
82 GUIDINI, Liz Bessa. Transações entre Partes Relacionadas. Relatório Anual PIBIC 2014. Pontifícia Universidade Católica do Rio de Janeiro - PUC - Rio.

${ }^{83}$ Disponível em: <https://www.mintz.com/newsletter/2012/Advisories/2214-0912-NAT-LIT/index. html $>$ Acesso em: 30 de mai. 2018.

${ }^{84}$ Disponível em: 〈http://www.ibgc.org.br/userfiles/files/Carta Diretriz 4.pdf>Acesso em: 30 de mai. 2018.
} 
obrigação, efetivamente, negociar, a fim de melhor atender ao interesse da companhia que representam, em cumprimento dos seus deveres fiduciários" $"$, fortalecendo o já previsto no art. $245^{86}$ da Lei de Sociedades Anônimas.

A carta diretriz estabelece ainda recomendações no intuito de contribuir para "a instauração de um ambiente empresarial de transparência, confiança e ampla divulgação de informações sobre as TPRs no Brasil" "87. Dentre as orientações, estão a criação de uma Política Interna ${ }^{88}$ para disciplinar e monitorar as Transações entre Partes Relacionadas e a criação de um Comitê Especial Independente.

Se destaca ainda, a orientação de que no caso de conflito de interesses, o profissional que possua interesse conflitante na transação, deve informar esse interesse e "abster-se de participar dos processos negocial e decisório relativo à TPR”. Além disso, orienta-se que Reorganizações Societárias envolvendo Partes Relacionadas se submetam ao crivo do Comitê de Aquisições e Fusões e ao seu Código de Autorregulação.

\subsubsection{Associação Brasileira das Companhias Abertas (ABRASCA)}

\footnotetext{
${ }^{85}$ IBGC - Instituto Brasileiro de Governança Coorporativa, Carta Diretriz n ${ }^{\circ} 4$ - Transações entre Partes Relacionadas, p. 12.

${ }^{86}$ Art. 245. Os administradores não podem, em prejuízo da companhia, favorecer sociedade coligada, controladora ou controlada, cumprindo-lhes zelar para que as operações entre as sociedades, se houver, observem condições estritamente comutativas, ou com pagamento compensatório adequado; e respondem perante a companhia pelas perdas e danos resultantes de atos praticados com infração ao disposto neste artigo.

${ }^{87}$ IBGC - Instituto Brasileiro de Governança Coorporativa, Carta Diretriz n ${ }^{\circ} 4$ - Transações entre Partes Relacionadas, p. 21.

${ }^{88}$ Tal política deve “(i) contemplar procedimentos sistemáticos, objetivos, impessoais para a análise e divulgação de TPRs, (ii) definir medidas e procedimentos a serem seguidos para tratar de conflito de interesses, (iii) estabelecerforos decisórios claros e efetivos e fixar atribuições negociais e deliberativas aos diversos órgãos sociais, de acordo com a materialidade da TPR, (iv) garantir o caráter estritamente comutativo à sociedade e (v) ter como objetivo zelar pelo interesse da companhia e garantir um tratamento equitativo entre todos seus sócios;"
} 
O capítulo 6 do Código ABRASCA de autorregulação e boas práticas das companhias abertas ${ }^{89}$, regulamenta as operações com partes relacionadas ${ }^{90}$. Ao analisar o documento, se verifica que suas normas estão divididas entre princípios e regras.

Ainda em seu capítulo 1, onde estão os objetivos e a abrangência do regulamento, já se recomenda como princípio básico que "O conselho de administração deve considerar a criação de comitês de assessoramento, para que assuntos complexos e especializados sejam analisados em profundidade.", bem como, "a participação de ao menos um Conselheiro Independente nos Comitês que tenham por atribuição (...) conflito de interesses, operações com partes relacionadas, remuneração de administradores e indicação de conselheiros".

Em seu capítulo 6, o código estabelece como princípio das operações com partes relacionadas, que "o conselho de administração e a diretoria devem zelar para que as operações com partes relacionadas, se houver, sejam contratadas em condições estritamente comutativas ou com pagamento compensatório adequado".

Em síntese, dentre as principais regras que o código determina para este tipo de operação, destacam-se as que determinam que (i) o conselho de administração deve aprovar uma política de operações com partes relacionadas ${ }^{91}$; (ii) o conselho de administração, ou o órgão competente, deve

\footnotetext{
${ }^{89}$ Disponível $\quad$ em: $\quad$ http://www.abrasca.org.br/Uploads/autoregulacao/codigo Abrasca de Autorregulacao e Boas Praticas das Companhias Abertas.pdf>Acesso em_30 de mai. 2018.

$90 \mathrm{O}$ documento define parte relacionada como "a parte que está relacionada com a entidade: (a) direta ou indiretamente por meio de um ou mais intermediários, quando a parte: (i) controlar, for controlada por, ou estiver sob o controle comum da entidade (is so inclui controladoras ou controladas); (ii) tiver interesse na entidade que lhe confira influência significativa sobre a entidade; ou (iii) tiver controle conjunto sobre a entidade; (b) se for coligada da entidade; (c) se for joint venture (empreendimento conjunto) em que a entidade seja um investidor; (d) se for membro do pessoal-chave da administração da entidade ou de sua controladora; (e) se for membro próximo da família ou de qualquer pessoa referido nas alíneas (a) ou (d); (f) se for entidade controlada, controlada em conjunto ou significativamente influenciada por, ou em que o poder de voto significativo nessa entidade resida em, direta ou indiretamente, qualquer pessoa referida nas alíneas (d) ou (e); ou (g) se for plano de benefícios pósemprego para benefício dos empregados da entidade, ou de qualquer entidade que seja parte relacionada dessa entidade."

91 A política de operações com Partes Relacionadas deve ser disponibilizada no website da Companhia.
} 
monitorar as operações com partes relacionadas; (iii) a diretoria deve cumprir e executar todas as políticas de operações com partes relacionadas, bem como os processos para monitoramento e divulgação dessas operações; (iv) o conselho de administração e a diretoria devem se certificar de que as operações entre a Companhia e suas partes relacionadas sejam formalizadas por escrito e em condições estritamente comutativas ou com pagamento compensatório adequado $^{92}$, se houver; (v) o conselho de administração deve vedar quaisquer empréstimos em favor do controlador, de acionistas que detenham participação relevante na Companhia ou de pessoas controladas ou sob o controle comum do controlador ou em favor de qualquer administrador das pessoas mencionadas anteriormente, exceto em favor de controladas ou coligadas da Companhia; e (vi) o conselho de administração e a diretoria devem promover ampla divulgação dos contratos entre a Companhia e suas partes relacionadas ao mercado, quando a contratação configure ato ou fato relevante ou quando da divulgação das demonstrações financeiras.

Por fim, o código define ser recomendável que (i) o conselho de administração vede a celebração de contratos de prestação de serviços pela Companhia com partes relacionadas, que envolvam remuneração por meio da cobrança de taxa de gestão (managementfee); (ii) o conselho de administração vede a celebração de contratos de prestação de serviços pela Companhia com partes relacionadas, que contenham cláusula de remuneração baseada em medida de desempenho econômico operacional da Companhia, tal como faturamento, receita, geração operacional de caixa (EBITDA), lucro líquido ou do valor de mercado, ou que de outra forma envolvam remuneração não justificável ou desproporcional em termos de geração de valor para a Companhia; e (iii) o conselho de administração não aprove operações com partes relacionadas, sempre que houver voto ou parecer contrário de todos os

\footnotetext{
92 O pagamento compensatório adequado dever ser compatível com as condições usuais de mercado.
} 
Conselheiros Independentes, ou de todos os membros externos de comitês do conselho de administração que preencham os requisitos de independência aplicáveis aos Conselheiros Independentes. 


\section{Capítulo 4 - A regulamentação de Transações entre partes relacionadas em outras jurisdições}

\subsection{União Europeia}

A Diretiva 2017/828 do parlamento europeu e do conselho, de 17 de maio de 2017, que altera a Diretiva 2007/36/CE no que se refere aos incentivos ao envolvimento dos acionistas a longo prazo, foi publicada em 20 de maio e estabelece novas normas para transações entre partes relacionadas ${ }^{93}$.

De acordo com o disposto na diretiva, 'transações com partes relacionadas podem prejudicar as sociedades e os seus acionistas, uma vez que podem proporcionar à parte relacionada a oportunidade de se apropriar de uma parte do valor de uma sociedade". Nesse sentido, se faz necessário um tratamento adequado para garantir a proteção dos interesses das sociedades e dos acionistas neste tipo de transação e

Os Estados-Membros deverão garantir que as transações relevantes com partes relacionadas sejam submetidas à aprovação dos acionistas ou do órgão de administração ou de supervisão, segundo procedimentos que impeçam a parte relacionada de explorar a sua posição e que ofereçam uma proteção adequada dos interesses da sociedade e dos acionistas que não sejam partes relacionadas, incluindo os acionistas minoritários. ${ }^{94}$

Além disso, a diretiva dispõe que "caso a transação com uma parte relacionada envolva um administrador ou um acionista, estes não deverão participar na aprovação ou na votação”, podendo os Estados-Membros autorizar um acionista que seja uma parte relacionada a participar na votação. ${ }^{95}$ No caso

\footnotetext{
93 A diretiva define "Parte relacionada" como uma parte relacionada na aceção das normas internacionais de contabilidade adotadas nos termos do Regulamento (CE) n.o 1606/2002 do Parlamento Europeu e do Conselho, de 19 de julho de 2002, relativo à aplicação das normas internacionais de contabilidade.

${ }^{94}$ Diretiva 2017/828 do parlamento europeu e do conselho, de 17 de maio de 2017.

95 Para que o acionis ta pos s a participar da votação, o direito nacional deve prever "garantias adequadas relativamente ao process o de votação que protejam os interesses das sociedades e dos acionis tas que não
} 
do administrador, não é possível que sua participação na aprovação ou na votação seja autorizada.

A nova norma, dispõe ainda que as sociedades deverão anunciar as transações relevantes ${ }^{96}$, identificando (i) a parte relacionada, (ii) a data e o valor da transação e (iii) outras informações necessárias para avaliar o equilíbrio da transação.

De acordo com o art. $9^{\circ}$ - C da Diretiva, os Estados-Membros devem definir as transações entre partes relacionadas relevantes, tendo em conta: (a) a influência que as informações sobre a transação podem ter sobre as decisões económicas dos acionistas da sociedade; (b) o risco decorrente da transação para a sociedade e para os seus acionistas que não sejam partes relacionadas, incluindo os acionistas minoritários.

Após definirem tais transações relevantes, os Estados-Membros devem assegurar que as sociedades anunciem publicamente as transações relevantes com partes relacionadas, nos moldes citados anteriormente. ${ }^{97}$

Os Estados-Membros devem ainda assegurar que as transações relevantes com partes relacionadas sejam aprovadas pela assembleia-geral ou pelo órgão de administração ou de supervisão da sociedade segundo procedimentos que impeçam as partes relacionadas de explorar a sua posição e que ofereçam uma proteção adequada dos interesses da sociedade e dos acionistas que não são partes relacionadas.

Transações entre partes relacionadas realizadas no quadro da atividade sociais e celebradas em condições normais de mercado recebem um tratamento

\footnotetext{
são partes relacionadas, incluindo os acionistas minoritários, como, por exemplo, uma maioria mais elevada para a aprovação das transações".

96 Até o momento da celebração da transação.

97 Além disso, os Estados-Membros podem prever que o anúncio seja acompanhado de um relatório que avalie se a transação é justa e razoável do ponto de vis ta da sociedade e dos acionis tas que não são partes relacionadas, incluindo os acionistas minoritários, e que explique os pressupostos em que se baseia e os métodos utilizados. As partes relacionadas não devem participar na elaboração do relatório.
} 
diferenciado ${ }^{98}$. Para essas operações, o órgão de administração ou de supervisão da sociedade deve estabelecer um procedimento interno para avaliar periodicamente se estas condições são cumpridas, sem a participação da parte relacionada.

\subsection{Estados Unidos}

\subsubsection{Statement of Finacial Accounting Standards}

O Statement of Financial Accounting Standards No. 57, ${ }^{99}$ de março de 1982, editado pela Financial Accounting Standards Board (FASB) ${ }^{100}$ estabelece normas para divulgação de operações entre partes relacionadas.

Segundo o dever de "disclosure", as demonstrações financeiras devem divulgar transações entre partes relacionadas relevantes. A divulgação deve incluir (i) a natureza da relação entre as partes relacionadas; (ii) a descrição da transação; (iii) o valor em dólares da transação; (iv) valores devidos por ou às partes relacionadas a partir da data de cada balanço apresentado.

Além disso, o documento enuncia que não se pode presumir que as transações envolvendo partes relacionadas sejam realizadas "on na arm's-lenght basis”, uma vez que as condições necessárias para transações competitivas de livre mercado podem não existir.

\footnotetext{
${ }^{98}$ Não obstante o tratamento diferenciado recebido pelas TPRs realizadas no quadro de atividades correntes e celebradas em condições normais de mercados, os Estados -Membros podem determinar que todas as normas referentes às transações entre partes relacionadas, sejam aplicadas à estas TPRs.

${ }^{99}$ Disponível em: $\quad \underline{\text { http://www.fasb.org/jsp/FASB/Document C/DocumentPage?cid=121822012 }}$ 7001\&acceptedDisclaimer=true > Acesso em 20 de mai. 2018.

${ }^{100}$ Established in 1973, the Financial Accounting Standards Board (FASB) is the independent, privatesector, not-for-profit organization based in Norwalk, Connecticut, that es tablishes financial accounting and reporting standards for public and private companies and not-for-profit organizations that follow Generally Accepted Accounting Principles (GAAP). 〉 More. Tradução livre: Fundado em 1973, o Financial Accounting Standards Board (FASB) é uma organização privada independente e sem fins lucrativos, com sede em Norwalk, Connecticut, que estabelece normas contábeis e de relatórios financeiros para empresas públicas e privadas e para organizações sem fins lucrativos, que seguem Princípios Contábeis Geralmente Aceitos (GAAP).
} 


\subsubsection{General Corporation Law (Delaware)}

A Lei de Delaware não menciona expressamente partes relacionadas. No entanto, considerando a descrição do tipo de relação regulamentada em seu título 8, capítulo I, entende-se que as normas abaixo devem ser observadas em transações entre partes relacionadas.

De acordo com o título 8 da Lei de Delaware ${ }^{101}$, nenhuma transação entre a "Corporation" e seus diretores ou administradores, deve ser nula ou anulada, exclusivamente por que esses (i) possuem interesses financeiros na transação, (ii) participaram de uma reunião do conselho ou comitê que autorizou a contratação, ou (iii) tiveram seu voto contabilizado para aprovar a transação.

No entanto, para que sua validade não seja prejudicada, é preciso verificar se os fatos relevantes - quanto ao relacionamento ou interesse do diretor ou do administrador e quanto ao contrato ou transação - foram devidamente divulgados ou são do conhecimento (i) do conselho de administração, do comitê ou (ii) dos acionistas autorizados a votar. Também é preciso observar se quem autorizou a transação, o fez de boa-fé.

Isso porque, a transação é justa para a "corporation" a partir do momento em que é autorizada, aprovada ou ratificada, pelo conselho de administração, por um comitê ou pelos acionistas ${ }^{102}$.

101 Disponível em: 〈http://delcode.delaware.gov/title8/c001/sc01/index.shtml $>$ Acesso em 20.de mai. 2018.

${ }^{102}$ Sendo a maioria dos acionistas desinteressados. 


\section{Capítulo 5 - A Responsabilidade do Administrador em Transações entre Partes Relacionadas}

Em regra, o administrador não é pessoalmente responsável pelas obrigações que contrair em nome da sociedade. Tal disposição está enunciada art. $158^{103}$ da Lei de Sociedades Anônimas e aplica-se aos atos regulares de gestão dos administradores.

Entretanto, quando o administrador age dentro de suas atribuições, com (i) culpa ou dolo, ou (ii) violação da lei ou do estatuto e causa prejuízos à sociedade, este responde civilmente ${ }^{104}$.

Em que pese a regra do geral do processo civil, estabeleça que cabe ao autor o ônus da prova, na análise da responsabilidade do administrador, alguns doutrinadores $^{105}$ entendem que é preciso analisar a natureza do dever supostamente descumprido pelo administrador: objetiva ou subjetiva.

${ }^{103}$ Art. 158 Lei n. 6.404 de 1976 - "O administrador não é pessoalmente responsávelpelas obrigaçoes que contrair em nome da sociedade e em virtude de ato regular de gestão; responde, porém, civilmente, pelos prejuízos que causar, quando proceder:

I - dentro de suas atribuições ou poderes, com culpa ou dolo;

II - com violação da lei ou do estatuto.

$\S 1^{\circ} \mathrm{O}$ administrador não é responsável por atos ilícitos de outros administradores, salvo se com eles for conivente, se negligenciar em descobri-los ou se, deles tendo conhecimento, deixar de agir para impedir a sua prática. Exime-se de responsabilidade o administrador dissidente que faça consignar sua divergência em ata de reunião do órgão de administração ou, não sendo possível, dela dê ciência imediata e por escrito ao órgão da administração, no conselho fiscal, se em funcionamento, ou à assembléia-geral. $\S 2^{\circ}$ Os administradores são solidariamente responsáveis pelos prejuízos causados em virtude do não cumprimento dos deveres impostos por lei para assegurar o funcionamento normal da companhia, ainda que, pelo estatuto, tais deveres não caibam a todos eles.

$\S 3^{\circ}$ Nas companhias abertas, a responsabilidade de que trata o $\S 2^{\circ}$ ficará restrita, ressalvado o disposto no $\S 4^{\circ}$, aos administradores que, por disposição do estatuto, tenham atribuição específica de dar cumprimento àqueles deveres.

$\S 4^{\circ} \mathrm{O}$ administrador que, tendo conhecimento do não cumprimento desses deveres por seu predecessor, ou pelo administrador competente nos termos do $\S 3^{\circ}$, deixar de comunicar o fato a assembléia-geral, tornar-se-á por ele solidariamente responsável.

$\S 5^{\circ}$ Responderá solidariamente com o administrador quem, com o fim de obter vantagem para si ou para outrem, concorrer para a prática de ato com violação da lei ou do estatuto.

104 Art. 153. O administrador da companhia deve empregar, no exercício de suas funções, o cuidadoe diligência que todo homem ativo e probo costuma empregar na administração dos seus próprios negócios.

105 ADAMEK, Marcelo Vieira Von. Op. cit., p. 194 e seguintes e PARENTE, Norma Jonssen; coordenação CARVALHOSA, Modesto, Op. cit., p. 495. 
Quando o dever tem natureza objetiva e seu cumprimento, ou não, se verifica de forma direta e clara, sustentável a adoção da responsabilidade objetiva do administrador, sem discussão de culpa, ou ao menos, presumindo-se a culpa do administrador. ${ }^{106}$ Por outro lado, deveres subjetivos como os deveres de lealdade, diligência, não devem se submeter à mesma regra. Nesses casos, a companhia deve provar a culpa ou o dolo do administrador na conduta danosa.

Adotando-se a teoria formal do conflito de interesses, a atuação conflituosa também poderia ser detectada de forma objetiva. Por essa linha, seria possível sustentar a responsabilidade objetiva do administrador, sem necessidade de provar sua culpa. No entanto, é preciso reconhecer que o posicionamento da CVM sobre o tema é oscilante.

Por outro lado, Sampaio Campos sustenta que a chave interpretativa do sistema de responsabilidade do administrador é o dever de diligência (art. 153 da Lei de Sociedades Anônimas) e destaca a necessidade de moderação na análise da responsabilidade do administrador para não o desencorajar em sua função.

Nesse sentido, enuncia sobre o sistema de responsabilidade civil do administrador que "Desdobramento natural desse sistema e dessa preocupação é a adoção da responsabilidade com base na culpa própria - ainda que em certos casos se admita a inversão do ônus da prova - e o repúdio à responsabilidade objetiva." 107

Apesar das divergências doutrinárias sobre a responsabilidade do administrador, a adoção de parâmetros para análise da conduta do administrador são nitidamente um grande passo para não o desencorajar na tomada de decisões, bem como garantir sua discricionariedade. Além disso, possibilita verificar sobre quem recai o ônus da prova, quando suscitada violação de seus deveres. Veja-se.

\footnotetext{
106 Ibid, p. 533.

107 SAMPAIO CAMPOS, Luiz Antonio de. Op. cit., 870.
} 


\subsection{Parâmetros para verificação da conduta do administrador: a business judgment rule e o fairness test}

Em regra, as decisões tomadas pelos administradores ${ }^{108}$ costumam ser mais criticadas ou analisadas, quando não atingem o fim pretendido. No entanto, como o risco é inerente à empresa, o direito estabelece padrões de conduta, que uma vez preenchidos, garantem proteção ao administrador na tomada de decisão, ainda que esta não tenha sido bem-sucedida, ou não tenha trazido o melhor resultado para a companhia.

Nesse sentido, nas palavras de Adamek, "o administrador obriga-se apenas a adotar comportamento apropriado, com a diligência requerida, para a consecução de determinado fim, (...) mas não se obriga pela efetiva obtenção do resultado". ${ }^{109} 110$

Tal pequena introdução sobre a tomada de decisão do administrador, se faz necessária para explicar a business judgment rule, regra que se desenvolveu na jurisprudência norte-americana no julgamento de ações de responsabilidade do administrador e é utilizada como standard na verificação do cumprimento ou não - do seu dever de diligência.

Conforme será demonstrado mais à frente, a business judgment rule não deve ser utilizada em transações entre partes relacionadas, ante a ausência de

\footnotetext{
108 Nelson Eizirik, a esse respeito escreve: “(...) na atuação do administrador só existe uma vontade, que é da sociedade, a qual se manifesta pelos membros do órgão dotado de competência para tanto (...) Os administradores, investidos do 'poder de representação', agem como se fossem a companhia, já que a administração de que participam constitui um órgão integrante da estrutura da pessoa jurídica". EIZIRIK, Nelson. A Lei das S/A Comentada. Vol. 2. São Paulo: Quartier Latin, 2011, p. 303.

${ }^{109}$ Adamek, Marcelo Vieira Von. Op cit., p. 132.

110 "A responsabilidade é, assim, apenas da companhia quando são praticados atos regulares de gestão realizados com observância da lei e dos estatutos, aí incluídos os padrões de conduta, perpetrados com o fito de realização do objeto social, ainda que resultem em operações malsucedidas.

A responsabilidade pessoal do administrador somente ocorrerá, caso sejam ultrapassadas as prerrogativas a ele conferidas, causando prejuízo à companhia ou se, valendo-se do cargo que ocupa, utilizar do patrimônio social para fins próprios". PARENTE, Norma Jonssen; coordenação CARVALHOSA, Modesto, Op. cit., p. 525.
} 
independência do administrador. Nesses casos, o parâmetro que deve ser utilizado para verificar sua conduta é o fairness test.

Para que seja aplicado o fairness test é preciso afastar a aplicação da business judgement rule. Por esse motivo, essencial o entendimento de ambos os parâmetros.

\subsubsection{A Business Judgment Rule}

A business judgment rule é a peça central do direito societário de Delaware. De acordo com site de seu próprio governo ${ }^{111}$ :

A lei de Delaware oferece aos membros do conselho de administração incumbidos de tomar estas decisões uma gama de presunções - conhecidas como a regra do "business judgment rule" - que, tomando por consideração o fato da maioria dos administradores e membros do conselho de administração não possuir interesses conflitantes (...) com relação à decisão, a sua decisão não será adiante questionada (ou "second-guessed") pelo judiciário se tomada com o devido cuidado e em boa-fé. A "business judgment rule", regra aplicada até mesmo quando a decisão tomada é posteriormente classificada como imprudente.

Conforme decidido no caso Aronson v. Lewis ${ }^{112}$, em 1984, a businnes judgment rule é a presunção de que os diretores da sociedade tomaram a decisão negocial de forma informada, de boa fé e acreditando ser no melhor interesse da companhia. ${ }^{113}$

Quando, eventualmente, suscitada violação aos deveres do administrador, se aplicada a business judgment rule, o processo decisório que levou a tomada da decisão questionada deve ser analisado e não o mérito da questão em si.

A principal consequência da verificação da devida aplicação do instituto é o afastamento da presunção de culpa do administrador que agiu de acordo com

\footnotetext{
111 Disponível em: 〈https://corplaw.delaware.gov/por/delaware way/> Acesso em: 22 de mai. 2018.

112 Aronson v. Lewis, 473 A.2d 805, 812 (Del. 1984).

${ }^{113}$ Standards of review in conflict transactions on motions to dismiss: lessons learned in the past decade by Lewis H. Lazarus, ESQ. \& Brett M. Mccartney, ESQ.
} 
os preceitos de referida norma. Sendo assim, ainda que por um risco do negócio a transação não seja boa para a companhia, presume-se que o administrador agiu de boa-fé no exercício de sua função, de modo que o julgador não poderá responsabilizá-lo.

\subsubsection{Os elementos da business judgment rule}

A business judgment rule trata-se de uma presunção composta por quatro elementos: (i) decisão negocial; (ii) desinteresse e independência; (iii) diligência; e (iv) boa-fé. ${ }^{114}$

O primeiro pressuposto para aplicação da regra é a existência de uma decisão negocial. Essa decisão não necessariamente precisa ser uma ação, podendo ser uma omissão, caso o administrador entenda que a melhor decisão seja não agir.

O segundo pressuposto para que a conduta do administrador seja protegida pela business judgment rule, é que a decisão do administrador não seja interessada e seja independente. Isso porque, se o administrador tem um interesse financeiro próprio na transação ou não é independente, grandes são as chances de que a decisão não seja tomada no interesse da companhia.

A Suprema Corte de Delaware, no caso Aronson v. Lewis, entendeu que (a) tem interesse na decisão o administrador que está nos dois lados da negociação e tem expectativa de auferir vantagens financeiras pessoais em

\footnotetext{
114 BRIGAGÃ O, Pedro Henrique Castello. A administração de Companhias e a Business Judgement Rule - São Paulo: Quartier Latin, 2017, p. 129/144.
} 
decorrência dessa situação e (b) é independente ${ }^{115}$ a decisão que se fundamenta estritamente no interesse da companhia. ${ }^{116}$

No entendimento de Delaware, conforme se verá no item 5.1.2, na ausência de independência do administrador ou caso seja verificado seu interesse financeiro na transação, afasta-se a aplicação da business judgment rule e o parâmetro para verificação da conduta do administrador passa a ser o fairness test. No Brasil, casos em que o administrador tem interesse financeiro próprio na transação, muitas vezes são tratados pelas normas do conflito de interesses ${ }^{117}$.

A terceira exigência para a aplicação da business judgment rule é a $\underline{\text { atuação diligente }}^{118}$ do administrador. $\mathrm{O}$ foco da análise do dever de diligência deve ser o processo de tomada de decisão do administrador e não o mérito de sua decisão.

Diversos padrões de comportamento esperados do administrador podem ser extraídos da legislação e da jurisprudência para verificar se o administrador foi diligente. Dentre eles, destaca-se a preocupação de que o administrador decida de forma informada.

Sobre o tema, o diretor da CVM Pedro Marcilio destacou, no julgamento do PAS CVM n 21/2004, ser impossível reproduzir a posteriori as exatas condições do processo de tomada de decisão e, tendo sido tomadas de forma desinteressada e em boa-fé, não podem os administradores serem acusados com base em uma situação ideal de conhecimento total das informações e quando o tempo não é escasso. ${ }^{119}$

\footnotetext{
115 Nas palavras de Pedro Brigagão, "o administrador perderá sua independência se for dominado ou fortemente influenciado por alguém que se beneficiará com a sua atuação, restando o seu poder de decisão enfraquecido a tal ponto que ele não mais se encontra isento para atuar nas respectivas matérias. Para ser considerado interessado, ao seu turno, o administrador deve auferir benefícios financeiros com o resultado de sua decisão." (BRIGAGÃO, Pedro Henrique Castello. A administração de Companhias e a Business Judgement Rule - São Paulo: Quartier Latin, 2017, p.136.)

116 BRIGAGÃO, Pedro Henrique Castello. A administração de Companhias e a Business Judgement Rule - São Paulo: Quartier Latin, 2017, p. 135-136.

117 As normas do conflito de interesses foram abordadas no item 3.4 do presente trabalho.

$118 \mathrm{O}$ dever de diligência foi abordado no item 3.1 do presente estudo.

119 BRIGAGÃO, Pedro Henrique Castello. A administração de Companhias e a Business Judgement Rule - São Paulo: Quartier Latin, 2017, p. 139.
} 
Por fim, para que seja aplicada a business jugment rule, o quarto pressuposto, é preciso que a decisão seja tomada de boa-fé.

É preciso ter grande cuidado na verificação da boa-fé na tomada de decisão negocial, sob pena de analisar o mérito da própria decisão.

A corte de Chancelaria de Delaware, no caso Walt Disney Co Derivative Litigation considerou que a má-fé em decisões negociais pode ser verificada na existência de dolo; falha escandalosa no processo decisório; ou indiferença consciente quanto aos negócios da companhia. ${ }^{120}$

Não obstante a importância do desenvolvimento da Business Judgement Rule para o desenvolvimento do mercado, ao que parece, esse não é o padrão ideal para a análise de transações entre partes relacionadas. É o que se passa a demonstrar.

\subsubsection{O Fairness test}

A jurisprudência norte-americana, para analisar a atuação do administrador em transações em que possui interesse conflitante ou que não possuí a devida independência, adotou ofairness test.

Tal paramêtro de verificação da conduta do administrador afasta a presunção de que esse agiu de boa-fé. Com efeito, cabe ao administrador provar que a transação foi aprovada por um comitê especial de conselheiros independentes ou pela maioria dos acionistas desinteressados.

Quando a diretoria não for composta em sua maioria por conselheiros desinteressados, as ações contestadas serão mantidas somente se forem justas para os acionistas. Nesse sentido, deve o administrador "provar que a operação o se deu de maneira totalmente justa aos intereses da companhia e de seus acionistas"121

\footnotetext{
${ }^{120}$ Ibid., p. 144.

${ }^{121}$ Ibid., p. 121.
} 
Conforme nos ensina Norma Jonssen Parente, em transações entre partes relacionadas a aplicação da Business Judgment Rule se mostra inadequada. Isso porque, entre partes independentes é presumida a independência do administrador, entretanto, não se pode presumir essa independência em transações entre partes relacionadas. ${ }^{122}$

A diretora Maria Helena Diniz, quando do julgamento do caso Splice (PAS CVM no RJ2005/0097) ${ }^{123}$ afirmou que:

Ao proibir a contratação com partes relacionadas em condições que prejudiquem a companhia, exigindo comutatividade ou pagamento compensatório adequado, a le i reconhece que, nessas transações, as partes envolvidas não têm o necessário distanciamento e inde pendência para negociar, tal como ocorreria nas ope rações realizadas com terceiros. ${ }^{124}$

Nas palavras de Fábio Konder Comparato:

(...) o nosso direito incoroporou, nesse particular, a experiência norte-americana do fairness test, consagrada jurisprudencialmente há mais de um século. Para os tribunais ianques, a celebração de um contrato entre companhia e seu diretor faz presumir o prejuízo para a sociedade e implica o ônus, para o administrador em causa, de provar a completa lisura da operação, segundo os parâmetros que a nossa lei veio a adotar: razoabilidade e habitualidade do negócio com terceiros. ${ }^{125}$

O conceito de Fairness Test desenvolvido pela jurisprudência norte americana, em síntese, caracteriza-se pela adoção de medidas para garantir a imparcialidade da operação.

\footnotetext{
122 PARENTE, Norma Jonssen; coordenação CARVALHOSA, Modesto, Op. cit., p. 545.

123 PAS CVM $\quad \mathrm{n}^{\circ}$ RJ2005/0097 $\quad$ Disponível em <http://www.cvm.gov.br/export/sites/cvm/sancionadores/sancionador/anexos/2007/20070315_PAS_R J20050097.pdf> Acesso em 20 de mai. 2018.

${ }^{124}$ Idem.

${ }^{125}$ Conforme voto de Leonardo Cantidiano no Processo CVM 2003/12.770, em 26.12.2003
} 
Diferentemente da Business Judgment Rule, que analisa apenas o processo de tomada de decisão, o Fairness Test analisa também o resultado da transação. Nesse sentido, ao se aplicar o instituto, cabe ao administrador provar que agiu de acordo com os padrões de conduta, bem como que a transação foi "fair". 126

É o que nos ensina Pedro Henrique Castello Brigagão:

Como escrevem Block et al., o entire fairness test foi arquitetado para identificar se a operação em xeque se manteria mesmo em cenários nos quais ela não é influenciada pelo administrador réu ${ }^{127}$. Conforme entendimento consolidado em seus julgamentos ${ }^{128}$, a Suprema Corte de Delaware analisa se uma decisão é justa por duas maneiras: uma por meio de suas negociações e outra por meio do preço estabelecido. $\mathrm{O}$ exame da integridade das negociações envolve questões como "when the transaction was timed, how it was initiated, structured, negotiated, disclosed to the diretor, and how the approvals of the directors and the stockholders were obtained" 129. $\mathrm{O}$ preço, ao seu turno, é avaliado considerando-se os aspectos econômicos e financeiros da operação, incluindo seus fatores relevantes, tais como os ativos envolvidos, o valor de mercado, receitas, perspectivas do negócio etc. ${ }^{130}$

De acordo com o entendimento adotado pela corte de Delaware, ante a existência de conflito de interesses, a decisão de administradores não será protegida pela business judgment rule, cabendo a esses demonstrarem que a transação "was entirely fair to the Corporation"”131

126 "And when those principles become applicable the necessary corollary, based upon the Supreme Court's opinion in Sterling v. Mayflower Hotel Corp., (...) is that the party owning the fiduciary duty has the burden of showing fairness." 261 A.2d 911 (Del. Ch. 1969)

127 BLOCK, Dennis J., BARTON, Nancy E.; RADIN, Stephen A. The Business Judgment Rule: Fiduciary Duties of Corporate Director. $6^{\mathrm{a}}$ ed. Vol. 1. New York: Aspen Publishers, 2009, p. 65.

128 Veja-se, por exemplo, Weinberger v. UOP, Inc., 457 A.2d 701(Del. 1993), International Telecharge, Inc. v. Bomarko, 766 A. 2d 437 (Del. 2000) e In re Digex, Inc Shareholders Litigation, 789 A.2d 1176 (Del. Ch. 2000)

${ }^{129}$ Weinberger v. UOP, Inc., 457 A. 2d 701 (Del. 1993)

${ }^{130}$ Idem.

131 "If a majority of the board has a conflicting interest in a transaction challenged in court, the board's decision may not be protected by the business judgment rule. Rather, Delaware courts will generally require the directors to demonstrate that a self-dealing transaction was entirely fair to the corporation. For that reason, the Delaware courts encourage interested directors to adopt procedural protectionslike impartial and independent decision-makers-to help ensure that the transactions are fair. Further, because Delaware law seeks to protect minority investors, major corporate transactions with controlling 
Em decisão da Suprema Corte de $1993^{132}$, se demonstrou de forma clara, que quando os diretores de uma corporação estão em ambos os lados de uma transação, eles são obrigados a demonstrar "their utmost good faith and the most scrupulous inherent fairness of the bargain".

De acordo com a decisão, o conceito de fairness tem dois princípios: (i) fair dealing e (ii) fair price. O primeiro diz respeito a questões sobre quando a transação aconteceu, como foi iniciada, estruturada, negociada, divulgada e como as aprovações dos diretores e acionistas foram obtidas. O segundo diz respeito às considerações econômicas e financeiras, incluindo fatores relevantes como ativos, valor de mercado, lucro, e quaisquer outros elementos que afetam as ações da companhia. O teste não é dividido em fair dealing e fair price. Todos os aspectos da questão devem ser examinados como um todo.

\subsubsection{Parâmetros para aplicação do fairness test}

No caso Orman v. Cullman ${ }^{133}$, julgado em 2002, a Court of Chancery sintetizou como afastar a aplicação da businnes judment rule para que seja aplicado o fairness test.

stockholders are subject to this searching fairness review even if procedural protections have been put in place." Tradução livre: Se a maioria do conselho tiver um interesse conflitante em uma transação contestada em juízo, a decisão do conselho pode não ser protegida pelo business judgment rule. Em vez disso, os tribunais de Delaware geralmente exigem que os diretores demonstrem que uma transação de self-dealing foi inteiramente justa para a corporação. Por essa razão, os tribunais de Delaware incentivam os diretores interessados a adotar proteções processuais - como tomadores de decisão imparciais e independentes - para ajudar a garantir que as transações sejam justas. Além disso, como as leis de Delaware buscam proteger os investidores minoritários, as principais transações corporativas com acionistas controladores estão sujeitas a essa revisão, mesmo que as proteções processuais tenhamsido implementadas. Disponível em: <https://corplaw.delaware.gov/por/delaware way/>Acesso em $20 \mathrm{de}$ mai. 2018.

132 Weinberger v. UOP, Inc 457 A.2d 701 (Supreme Court of Delaware 1983). Disponível em: <https://law.justia.com/cases/delaware/supreme-court/1983/457-a-2d-701-4.html> Acesso em 20 de mai. 2018.

133 Orman v. Cullman 794 A.2d 5, 22-23 (Del. Ch. 2002) (Standards of review in conflict transactions on motions to dismiss: lessons learned in the past decade by Lewis H. Lazarus, ESQ. \& Brett M. Mccartney, ESQ.) 
De modo geral, a aplicação da business judgment rule pode ser afastada, por meio da alegação de fatos que, se aceitos como verdadeiros, demonstram que o administrador era interessado no resultado da transação ou não tinha independência para considerar objetivamente se a transação foi no melhor interesse da companhia e de seus acionistas.

Não obstante, algumas salvaguardas podem ser adotadas para "devolver" o ônus da prova para o demandante para provar a "injustiça" da transação, como por exemplo a aprovação da transação por um comitê especial de diretores independentes e desinteressados e a exigência de aprovação por uma maioria de os acionistas minoritários da companhia.

Para refutar com sucesso a aplicação da businnes judment rule alcançando a aplicação do fairness test, o autor deve apresentar fatos que demonstrem que a maioria dos acusados tem interesse financeiro na transação ou foram influenciados por um diretor materialmente interessado.

Os ensinamentos da jurisprudência de Delaware demonstram que ante a ausência de independência do administrador, o fairness test deve ser aplicado, cabendo ao administrador o ônus da prova de demonstrar que a transação foi "justa".

Em transações entre partes relacionadas a existência de independência é altamente questionável. Nesse sentido, no próximo capítulo será demonstrado um possível caminho para aplicação do instituto no Brasil.

\subsection{Distribuição dinâmica do ônus da prova}

A distribuição dinâmica do ônus da prova, enunciada pelo art. $373, \S 1^{\circ}$, do Código de Processo Civil de 2015, enuncia que o ônus probatório recai sobre quem tiver melhor condição de produzir a prova, conforme as circunstâncias fáticas do caso. In verbis: 
Art. 373. O ônus da prova incumbe:

I - ao autor, quanto ao fato constitutivo de seu direito;

II - ao réu, quanto à existência de fato impeditivo, modificativo ou extintivo do direito do autor.

$\S 1^{\circ}$ Nos casos previstos em lei ou diante de peculiaridades da causa relacionadas à impossibilidade ou à excessiva dificuldade de cumprir o encargo nos termos do caput ou à maior facilidade de obtenção da prova do fato contrário, pode rá o juiz atribuir o ônus da prova de modo diverso, desde que o faça por decisão fundame ntada, caso em que deverá dar à parte a oportunidade de se desincumbir do ônus que lhe foi atribuído. (Grifo)

A inversão do ônus da prova no caso de conflito de interesses, conforme decidido pela Corte de Delaware no caso Sinclair Oil Corporation vs. Levien ${ }^{134}$, ocorre não exatamente porque o autor não tem condições, ou teria dificuldade na produção na prova, mas porque o administrador nesse tipo de transação deixa de ser considerado independente e sua atuação no interesse da companhia fica comprometida.

Assim, a distribuição dinâmica do ônus da prova, do direito brasileiro, não poderia ser aplicada, exclusivamente, pelo mesmo motivo pelo qual se altera o ônus da prova quando aplicado o fairness test.

Não obstante, se em decorrência do interesse do administrador na transação entre partes relacionadas se tornar onerosa a produção da prova, principalmente, considerando que é comum em alguns tipos de transações entre partes relacionadas a ausência de registros ou documentos oficiais, seria possível

\footnotetext{
134 "Plaintiff's case is grounded upon the premise that at pertinent times all directors and officers of Venezuelan were "saturated" with conflicts ofinterest because of thei remployment by or subservience to Sinclair to whom Venezuelan sold substantially all of its crude oil and oil products. Plaintiffcontends that Sinclair dominated and controlled Venezuelan and exercised its power in such away ("overreached") as to damage the Corporation and, in particular, the interest of its public (minority) stockholders. Specifically, he charges Sinclair with waste, mismanagement and the violation offiduciary duties". Tradução livre: O demandante se baseia na premissa de que, por determinado tempo, todos os administradores da Venezuelan estavam "saturados" com conflitos de interesse por causa do serviço prestado pela Sinclair, a quem a Venezuelan vendeu substancialmente todos os seus produtos petrolíferos. O demandante sustenta que a Sinclair é dominada e controlada pela Venezue lan e exerceu sua poder de um modo que causou dano sobre a corporação e, em particular, ao interes se dos acionis tas minoritários. Objetivamente, o demandante acusa Sinclair de desperdício, má administração e a violação dos deveres fiduciários.
} 
a inversão do ônus da prova, cabendo ao administrador provar que a transação foi no interesse da companhia.

Ademais, a teoria da distribuição dinâmica do ônus da prova garante um resultado mais justo ao processo, uma vez que ao modificar o ônus probatório, possibilita que tal ônus recaia sobre aquele que possui melhores condições de produzir a prova.

No caso de transações entre partes relacionadas, o ônus probatório merece um tratamento diferenciado, exatamente por esse motivo, pois ante a ausência de independência das partes, amplamente demonstrada ao longo do presente estudo, o administrador que atuou em transação entre partes relacionadas, é a pessoa que possui melhores condições de demonstrar que a transação se deu de forma independente, no interesse da companhia, alcançando o fair dealing e o fair price.

Com efeito, demonstrando que atuou de acordo com os parâmetros supracitados, o administrador afastaria sua responsabilidade. Isso porque atuando de forma independente, no interesse da companhia e alcançando o fair dealing e o fair price, o administrador estaria atuando de acordo com seus deveres fiduciários enunciados no capítulo $3^{135}$, bem como de acordo com os preceitos do art. $245^{136}$ da Lei de Sociedades Anônimas.

\footnotetext{
135 Os deveres dos administradores enunciados no capítulo 3 são: dever de diligência, dever de lealdade, dever de informar, deveres decorrentes do conflito de interesses, bem como deveres decorrentes de soft laws.

136 Art. 245. Os administradores não podem, em prejuízo da companhia, favorecer sociedade coligada, controladora ou controlada, cumprindo-lhes zelar para que as operações entre as sociedades, se houver, observem condições estritamente comutativas, ou com pagamento compensatório adequado; e respondem perante a companhia pelas perdas e danos resultantes de atos praticados com infração ao disposto neste artigo.
} 


\section{Conclusão}

A lei de Sociedades Anônimas apesar de não tratar expressamente de Transações entre Partes Relacionadas, enuncia deveres e responsabilidades dos administradores que auxiliam o tratamento da matéria.

No caso de sociedade coligada, controladora ou controlada, o art. 245 da lei deixa claro que o administrador não pode em prejuízo da companhia que administra favorecer aquelas sociedades. Determina ainda que tais operações devem observar condições estritamente comutativas, ou o pagamento compensatório adequado. ${ }^{137}$

Os deveres dos administradores de maior relevância ao se depararem com transações entre partes relacionadas são (i) os decorrentes de conflito de interesses, (ii) os desdobramentos do dever de informar, bem como (iii) os decorrentes de orientações da CVM e de órgãos auto reguladores no sentido de que as transações entre partes relacionadas sejam aprovadas por comitês independentes ou por acionistas desinteressados.

Destaca-se que a existência de um comitê independente formalmente constituído não garante a independência da transação. Ademais as recomendações do comitê devem ser submetidas a análise do administrador. Logo, o administrador não pode se eximir de seus deveres ante a existência do comitê.

Nesse sentido, observa-se que a responsabilidade do administrador, merece tratamento diferenciado no caso de transações entre partes relacionadas. Isso porque, a independência do administrador nessas transações é altamente questionável, assim a probabilidade de conflito de interesses é grande.

Conforme a jurisprudência de Delaware, verificada a ausência de independência ou o interesse do administrador da transação, o parâmetro de

\footnotetext{
137 Não obstante o disposto no art. 264 da Lei de Sociedades Anônimas, cumpre ao administrador observar os demais deveres enunciados na Lei de Sociedades Anônimas, bem como as instruções da CVM e as normas emanadas por instituições autoreguladoras.
} 
análise da conduta do administrador passa a ser o fairness test, cabendo a ele o ônus da prova de que a transação foi "justa". Já no Brasil, em que pese se reconheça que a independência de transações entre partes relacionadas é comprometida, não se verificou concretamente a inversão do ônus da prova por esse motivo.

Não obstante, conforme demonstrado no último capítulo, entende-se que a inversão do ônus da prova poderia ocorrer com a aplicação da distribuição dinâmica do ônus da prova.

Por fim, mas não menos importante, o presente trabalho destaca a importância que a Governança Corporativa tem para melhorar as práticas do mercado ${ }^{138139}$, principalmente, se tratando de transações entre partes relacionadas $^{140}$.

138 "A verdade é que, em matéria de corporate governance, as soluções não podem ser uniformemente aplicadas em todos os países, sem considerar as característ icas de cada mercado de capitais. Em países como Estados Unidos da América e Inglaterra, o mercado acionário caracteriza-se pela dispersão, com a pulverização de valores mobiliários em mãos de inúmeros investidores. Em outros mercados, como o da Alemanha, o do Japão e mesmo o do Brasil, há ao revés, maior concentração das ações, sobretudo em poder de investidores institucionais. É claro, pois, que as medidas e soluções preconizadas para aqueles países não podem ser pura e simplesmente transpostas para estes, sob pena de não surtirem o efeito esperado". ADAMEK, Marcelo Vieira Von. Op. cit., p. 117, citando Bem Pettet, Company law, cit., n. 3.4, p. 55-58; e SALOMÃO FILHO, Calixto, Direito societário e novo mercado. In: O novo direito societário, 3 ed., São Paulo: Malheiros, 2006, p. 51-53.

${ }^{139}$ Sampaio Campos ao escrever sobre o tema no livro o direito das companhias, defende que "embora se reconheça a importância do movimento da governança coorporativa, - que nas sábias palavras de Paul Davies no tradicional Gowers (1997, p. 66), é uma palavra moderna para uma questão tão antiga quanto o surgimento da grande companhia aberta- é fundamental se ter presente que muitas das suas sugestões e recomendações desde movimento devem ser apenas assim consideradas, e não como regra legal, que não são."139 SAMPAIO CAMPOS, Luiz Antonio de. Op. cit., p. 792.

140 A análise das normas das entidades autoreguladoras sobre transações entre partes relacionadas, permitem concluir entre as principais recomendações apontadas para mitigar possíveis problemas decorrentes de transações entre partes relacionadas, estão:(i) a implementação de políticas internas; (ii) a criação de comitês independente; (iii) o impedimento do administrador de atuar quando possuir interesse conflitante; e (iv) o dever de informar. 


\section{Referências Bibliográficas}

ADAMEK, Marcelo Vieira Von. Responsabilidade Civil dos Administradores de S/A (e as ações correlatas) - São Paulo: Saraiva, 2009.

BORBA, José Edwaldo Tavares. Direito societário. $13^{\mathrm{a}}$ ed. Rio de Janeiro: Renovar, 2003.

BRIGAGÃO, Pedro Henrique Castello. A administração de companhias e a business judgment rule - São Paulo: Quartier Latin, 2017.

CAMARGO, João Laudo de; BASTOS FILHO, Cláudio Luiz de Miranda. Transações entre partes relacionadas. In CASTRO, Leonardo Freitas de Moraes e (Org.). Mercado Financeiro \& de Capitais: Regulação e Tributação - São Paulo: Quartier Latin, 2015.

CUNHA, Rodrigo Ferraz Pimenta da, Estrutura de Interesses nas Sociedades Anônimas - Hierarquia e Conflitos - São Paulo: Quartier Latin, 2007

EIZIRIK, Nelson; GAAL, Ariadna B; PARENTE, Flávia; HENRIQUES, Marcus Freitas. Mercado de Capitais - regime jurídico. 3. ed. revista e ampliada. - Rio de Janeiro: Renovar, 2011.

GALGANO, Francesco. Tratado do conflito de interesses entre acionista e companhia, "La Società per Azioni". In Trattato di Diritto Commerciale e di Diritto Pubblico dell'Economia, v. 7 Padova, CEDAM, 1984. 
GUIDINI, Liz Bessa. Transações entre Partes Relacionadas. Relatório Anual PIBIC 2014. Pontifícia Universidade Católica do Rio de Janeiro - PUC - Rio.

SALOMÃO FILHO, Calixto, Direito societário e novo mercado. In: O novo direito societário, 3 ed., São Paulo: Malheiros, 2006.

SAMPAIO CAMPOS, Luiz Antonio de. Deveres e Responsabilidades. In LAMY FILHO, Alfredo; PEDREIRA, José Luiz Bulhões (Org.). Direito das Companhias. Rio de Janeiro: Forense, 2017.

PARENTE, Norma Jonssen; coordenação Modesto Carvalhosa. Mercado de Capitais. (Coleção Tratado de Direito Empresarial. v. 6). São Paulo: Editora Revista dos Tribunais, 2016, p. 545. 